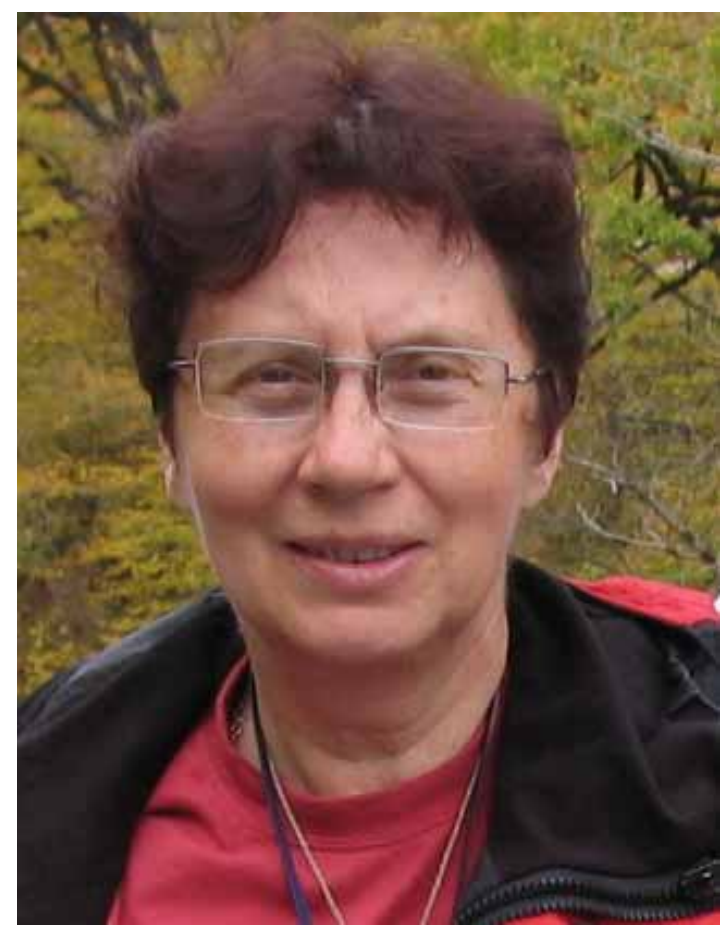

\section{TO NADEZHDA ALEKSEEVNA KONSTANTINOVA BIRTHDAY}

Nadezhda Alekseevna was born in Moscow, on September, 11, 1950, as the first child of Alexey Pavlovich Tyrtikov and Galina Stepanovna Konstantinova. Her father was a famous botanist and worked in the Institute of Geocryology of Academy of Sciences of USSR and also at the department of Plant Sociology of Faculty of Biology and Soil Sciences (later Biological Faculty) of Moscow University. Her mother, Galina Stepanovna Konstantinova, was a remarkable specialist in the geography of cryozones and worked for a long time at the Faculty of Geography in Moscow State University. Among friends and relatives of Nadezhda's parents there were many remarkable scientists in the fields of biology, geography and geology, and the young lady grew up in a creative environment amidst exciting stories and discussions about scientific problems.

A few years after Nadezhda was born, she, together with her parents, sister and brother moved to the Siberian Arctic, to the little town of Igarka, where her parents worked due to a special contract. She spent four years in Igarka, from 1957 to 1960 . At the age of seven Nadezhda visited a remote area nearby the Khantaika River in the course of a scientific expedition organized by her parents. That expedition made strong impact to Nadya's mentality and determined the choice of her future profession, namely plant sociology.

After she graduated from the public school in Moscow in 1967, Nadezhda entered the Faculty of Biology and Soil Science in Moscow State University. In the course of this study Nadezhda focused on research of the special subject in the department of plant sociology

\section{НАДЕЖДЕ АЛЕКСЕЕВНЕ КОНСТАНТИНОВОЙ КО ДНЮ РОЖДЕНИЯ}

Надежда Алексеевна Константинова родилась 11 сентября 1950 г. в Москве в семье научных сотрудников Института мерзлотоведения АН СССР. Мать - Галина Степановна Константинова - известный географмерзлотовед, в последние годы до выхода на пенсию работала на географическом факультете Московского государственного университета (МГУ). Отец - Алексей Павлович Тыртиков - известный ботаник, работавший с 1960 по 1986 гг. на кафедре геоботаники биологопочвенного, а потом биологического факультета МГУ в должности старшего научного сотрудника. Среди друзей и родственников родителей были известные ученые биологи, географы и геологи. Дома постоянно велись дискуссии и обсуждения серьезных научных проблем.

С 1957 по 1960 гг. вместе с родителями, сестрой Натальей и братом Сергеем, Надя жила за Полярным кругом, в городе Игарка, куда родители уехали работать по договору. В 7 лет родители взяли маленькую Надю в экспедицию на реку Хантайка (приток Енисея). Эта экспедиция оказалась определяющей в выборе профессии, в частности, геоботаники. Именно тогда она «заболела вирусом странствий», и вся ее последующая работа, вплоть до сегодняшнего дня, связана с экспедициями.

В 1967 г., сразу после окончания средней школы № 190 в Москве, Надежда Алексеевна поступила на биолого-почвенный факультет МГУ, который успешно закончила в 1973 г. В университете Надежда Алексеевна специализировалась на кафедре геоботаники и каждый год выезжала в экспедиции в северные регионы 


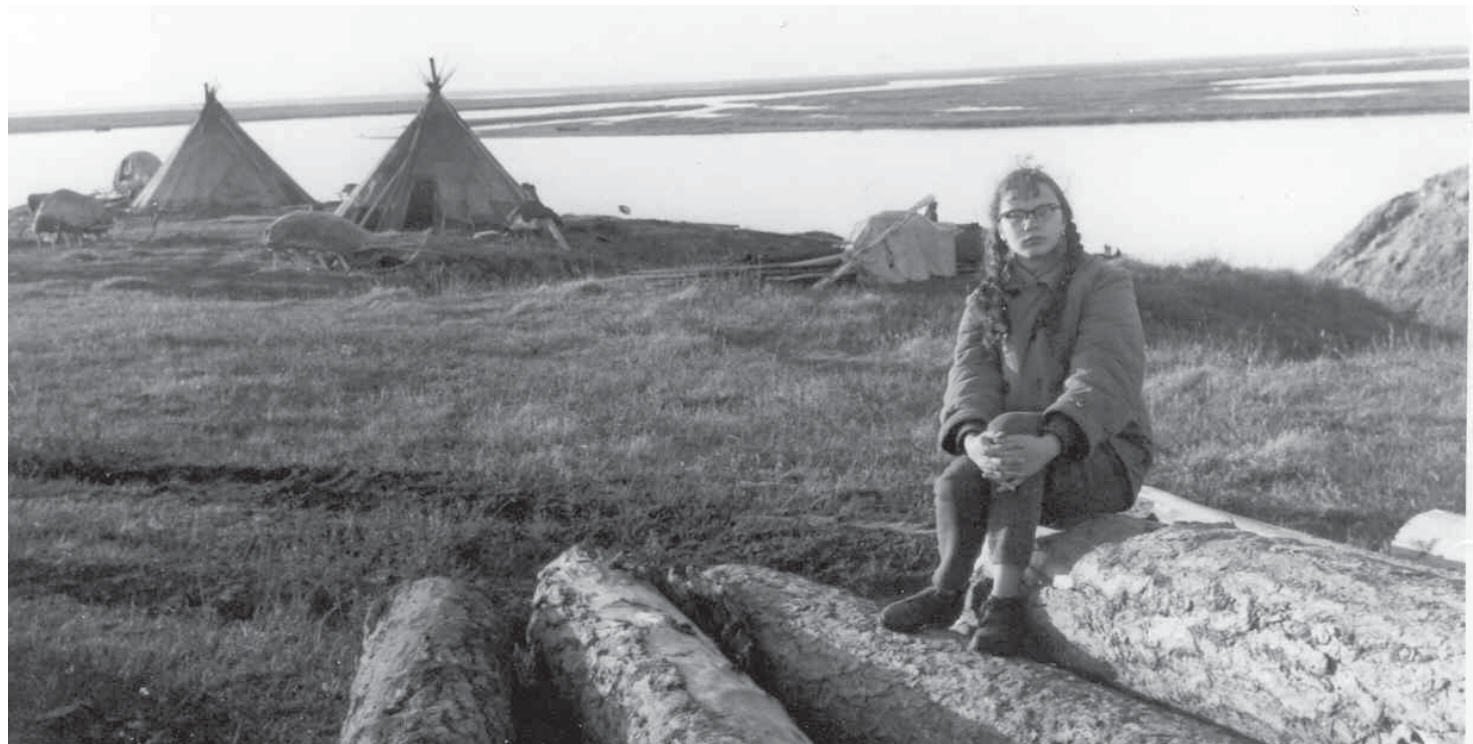

1966, Тазовский полуостров, север Западной Сибири — Tazovskij Peninsula, northern West Siberia

('geobotany' in Russian tradition) and visited various areas in Arctic zone of the former USSR: Taimyr, Yamal, Tazovsky Peninsulas, etc. Her bachelor thesis was about the characteristics of spotty tundras in Yamal. This event marked the turning point in her interests: from then on Nadezhda devoted her life to bryophytes. After four years of study she visited for the first time the Polar-Alpine Botanical Garden Institute, the northernmost outpost of botany in Soviet Union, and was charmed by northern nature and the creative environment in this place. At that time this botanical garden had brought together a team of highly qualified staff and experts in various fields of botany: R. N Schljakov, M.L. Ramenskaya, A.V. Dombrovskaya, L.N. Filatova. Nadezhda started her master course under supervision of the patriarch of Soviet Bryology, Dr. Roman Nikolayevich Schljakov. In 1973 she successfully graduated from the university and arrived at the Polar-Alpine Botanical Garden, and her scientific career is associated with this academic institute from this time up till now.

She received her PhD degree from Moscow University in 1979, having presented thesis "Flora of liverworts of Khibiny Mts."; Roman N. Schljakov was her doctoral advisor. Her thesis and data collected in the course of numerous field trips in Murmansk Province (Lovozersky Mts., Lavna-tundra, Chiltald and IonnN'yugoajv massifs, Kutsa Reserve, Kovdozero Lake area, etc.) served as background of the main book written by Nadezhda together with her supervisor: "Checklist of bryophytes of Murmansk Province".

In 1982 Nadezhda married the geologist Anatoliy Nikolayevich Savchenko and in the same year, their daughter Nadya (the same name as her mother) was born. Anatoliy was and still is the indispensable participant of Nadezhda's field trips who always helps his wife in expeditions and field researches.

The supervisor of Nadezhda, Dr. R.N. Schljakov,
CССР: работала на Таймыре, Ямале, Тазовском полуострове. Её курсовая работа была посвящена характеристике пятнистых тундр Ямала. После 4 курса на выполнение преддипломной практики она приехала в Полярно-альпийский ботанический сад к д.б.н. Роману Николаевичу Шлякову, к которому по окончании университета поступила в аспирантуру. Атмосфера, царившая в лаборатории флоры и растительных ресурсов, где в то время кроме Р.Н. Шлякова работали также М.Л. Раменская, А.В. Домбровская, Л.Н. Филиппова, произвела на Надежду Алексеевну большое впечатление. Поэтому сомнений, оставаться работать на Севере или вернуться в Москву, не было. Её дальнейшая судьба была связана с Заполярьем и ПАБСИ, куда она была принята на работу в лабораторию флоры и растительных ресурсов и где начала работу по выявлению гепатикофлоры Хибин.

В 1979 г. Надежда Алексеевна защитила в МГУ диссертацию “Флора печеночников Хибин”. Материалы, полученные во время работы в Хибинах, и позднее, на полуостровах Рыбачий, Средний и других районах, вошли в "Конспект флоры мохообразных Мурманской области”, написанный в соавторстве с Р.Н. Шляковым. В дальнейшем она продолжила исследования малоизученных районов Мурманской области Ловозерских гор, Лавна-тундры, массивов Чильтальд и Ионн-Ньюгоайв, островов Кандалакшского заповедника, заказника «Кутса», района Ковдозера и др.

В 1982 г. Надежда Алексеевна вышла замуж за геолога Анатолия Николаевича Савченко. Эта супружеская пара - пример замечательной семьи, посвятившей свою жизнь науке. Будучи совершенно разными по натуре, они дополняют друг друга. Анатолий Николаевич оберегает супругу от многих тягот и рутинных забот семейной жизни, все хлопоты по организации совместных экспедиций также он берет на себя. В том же году в семье родилась дочь 
1996, Санкт-

Петербург, БИН

Р.Н. Шляков (сидит) с ученицами (слева направо):

Г.В. Железнова,

О.А. Белкина,

Н.А. Константинова,

С.К. Гамбарян,

Е.Н. Андреева.

1996, Sankt-Petersburg, Komorov' Botanical Institute

R.N. Schljakov with his students (left to right):

G.V. Zheleznova

O.A. Belkina

N.A. Konstantinova

S.K. Gambaryan

E.N. Andrejeva

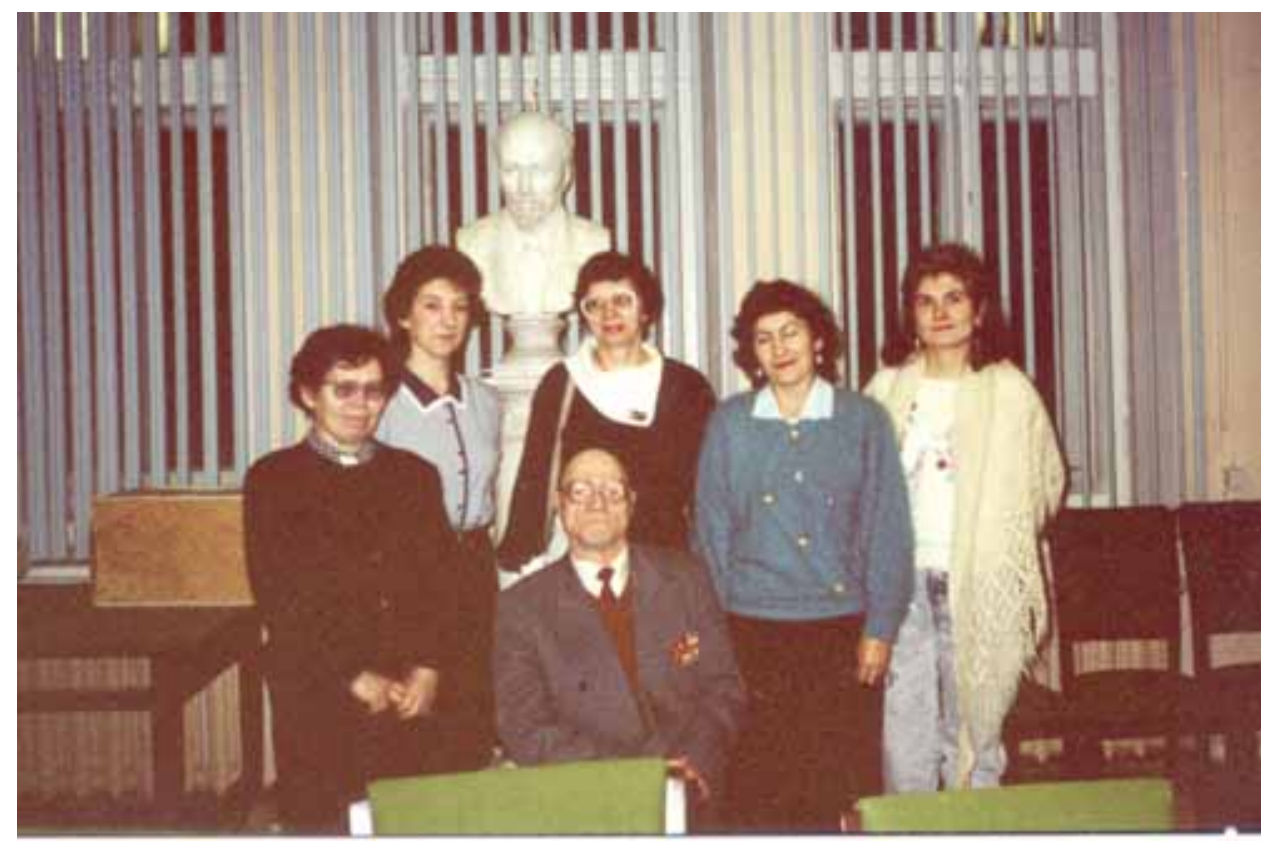

retired in 1984 and then Nadezhda became the leader of bryological group in the institute. Ten years later she was employed as the head of the Laboratory of the flora and vegetation that she has successfully been leading until the present time. During three years (2003-2006) Nadezhda was also a vice-director of the Institute.

In the beginning of the nineties the Soviet Union had disintegrated into several independent countries and the economy was in ruins. That was a very difficult time for Russian scientists too. However, despite the obstacles, these years were very fruitful in Nadezhda's life. Free contacts with foreign colleagues became possible, and she managed to organize the Seventh Meeting of bryologists in East and Central Europe. It was carried out in 1990 when 'top class' foreign and Russian bryologists, including the famous hepaticologist Riclef Grolle, assembled for a meeting and field excursions in Murmansk Province. The next International Bryological conference dedicated to 100 year anniversary of R.N. Schljakov and field school for early-stage researchers in bryology were held in Apatity in 2012.

In nineties Nadezhda visited twice the United States for field researches in collaboration with Diana Horton, Rudolf Schuster and many other famous bryologists. She also participated in a collaborative program of the Russian Federation and The Netherlands on "Biological diversity in different climates: The effects of climate change on the life-history of vernal species", and visited the Netherlands and Belgium in 1999.

Nadezhda never limited herself solely to the study of the Murmansk Province. She studied carefully miscellaneous herbarium collections from other areas of Russia. One of the first results of her work was the paper 'Vegetation of lake area in Central Yamal' in co-authorship with her father. In 1989 she published first results of a
Надежда, подарившая им в 2014 г. внучку Александру.

После выхода Р.Н. Шлякова на пенсию Надежда Алексеевна в 1984 г. возглавила бриологическую группу, затем - брио-лихенологическую, а в 1994 г. была избрана заведующей лабораторией флоры и растительных ресурсов и успешно руководит этой самой крупной лабораторией ПАБСИпо настоящее время. С 2003 по 2006 гг. Надежда Алексеевна выполняла обязанности заместителя директора ПАБСИ по научной работе.

Трудные 1990-е годы для Надежды Алексеевны были наиболее плодотворным временем. Знаковым для нее стал 1990 год, когда она организовала в Кировске Седьмой съезд Центрально-Европейской Ассоциации бриологов. Тогда в Мурманскую область съехался весь цвет европейской бриологии. В конференции приняла участие известный американский бриолог Дайяна Хортон (Diana Horton), с которой у Надежды Алексеевны завязались теплые дружеские отношения. Приехав в США по ее приглашению в 1992 г., Надежда Алексеевна посетила многие восточные штаты США, встречалась с Рудольфом Шустером (Rudolf Schuster). Они совершили совместную экспедицию на Южную Аляску. Летом 1994 г. Шустер нанес ответный визит в Россию. Вместе с Надеждой Алексеевной он посетил Москву, Санкт-Петербург и, в завершение визита, в Кировске состоялась встреча крупнейших гепатикологов современности - Р. Шустера и Р.Н. Шлякова. В 1995 г. Надежда Алексеевна вместе с А.Д. Потемкиным проводили исследования в США в рамках работы по проекту Национального географического общества по исследованию рода Marsupella во флоре Северной Америки. В 1999 Надежда Алексеевна участвовала в совместной российско-голландской программе "Biological diversity in different climates: The effects of climate change on the life-history of vernal species" и посетила 


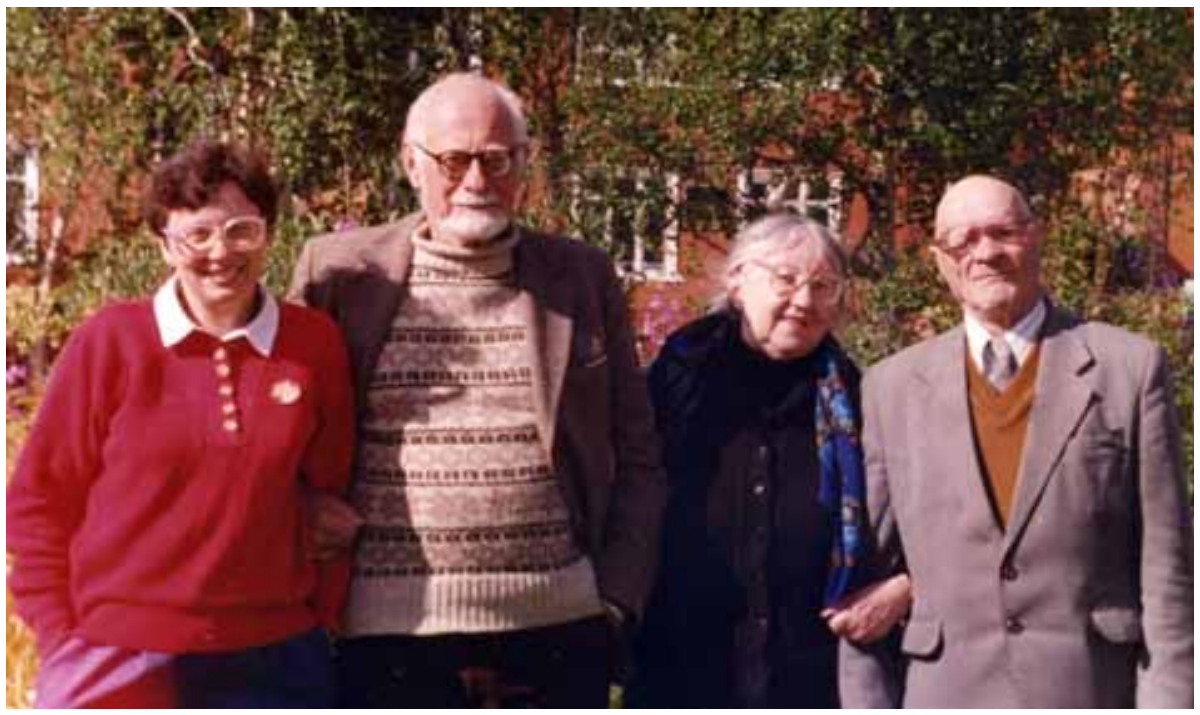

\section{ПАБСИ \\ Н.А. Константинова, \\ Р.М. Шустер, \\ А.В. Домбровская, \\ Р.Н. Шляков}

1994, Kirovsk, PolarAlpine Botanical Garden Institute

N.A. Konstantinova

R.M. Schuster

A.V. Dombrovskaya

R.N. Schljakov comparison of some liverwort floras of the North. Then she issued her noticeable papers on liverworts of Arkhangelsk Province, Sayan Mts, Polar Urals, and of Lena River Lower Course. These and other investigations not mentioned here formed the basis for the first checklist of Liverworts and Anthocerotae of the former USSR, the annotated list of liverworts of the Arctic, the list of liverworts in the State Nature Reserves of Russia and, finally, the Checklist of liverworts of Russia.

In 1998 Nadezhda successfully defended in Moscow University her second thesis for Doctor of Science degree: "The main features of liverwort floras of the northern Holarctic". She compared taxonomic spectra of liverworts in different sectors in the Holarctic and reexamined some hypotheses in botanical geography. Her classical paper "Distribution patterns of liverworts in northern Holarctic" was published a year later.

As mentioned above, one of Nadezhda's passions is the field research that forms the basis for future floristic and taxonomic studies. Every year Nadezhda takes part in expeditions to remote areas of Russia, sometimes under severe climatic conditions. In the field, she is a remarkable leader of the team, always going ahead with a lot of energy and not being tired or despaired. Moreover she is also an excellent organizer of field work and uses exhaustively every day of the expedition regardless of weather conditions. Nadezhda never loses heart in difficult situations; contrary, she always tries to find a solution of the problem. Regardless of her high status as the head of the Laboratory, she takes part in the expedition' routine duties: making fire, preparing food, drying specimens, etc. Communication with Nadezhda in the field is useful both for younger and for older colleagues.

In the course of numerous expeditions to various areas of Russia and adjacent countries Nadezhda gathered a 'vital' collection for various bryological works in Russia. She says about herself that she is mainly a floristic bryologist; however, in her career she was also frequently involved in taxonomic revisions of several
Нидерланды и Бельгию. В 2012 году при ее участии была проведена еще одна международная конференция, посвященная 100-летию со дня рождения ее учителя Р.Н. Шлякова.

Надежда Алексеевна никогда не ограничивалась изучением одной Мурманской области. Она определяет коллекции печеночников, собранных геоботаниками в различных труднодоступных районах страны, одним из результатов такой работы стала статья «Растительность озерного района Центрального Ямала», которую Надежда Алексеевна написала в соавторстве со своим отцом в 1980 г. В 1989 г. ею была предпринята попытка проанализировать особенности некоторых флор печеночников Севера (Константинова, 1989). Она активно изучала бриофлору различных регионов, в том числе по гербарным коллекциям. Результаты этих работ были отражены в ряде оригинальных статей по Архангельской области, Саянам, Полярному Уралу, низовьям реки Лена. Все они легли в основу крупных обобщений, сделанных Надеждой Алексеевной, таких как “Список печеночников территории бывшего СССР”, “Аннотированный список печеночников Арктики”, сводка "Печеночники и антоцеротовые заповедников России” и, наконец, чек-лист печеночников России. В 1998 году Надежда Алексеевна защитила докторскую диссертацию «Основные черты флор печеночников севера Голарктики». Сравнение ряда северных флор печеночников между собой позволило переосмыслить известные ботанико-географические закономерности. По материалам диссертации была написана ставшая уже классической статья “Анализ ареалов печеночников севера Голарктики".

Н.А. Константинову нельзя назвать исключительно кабинетным ученым. Считая полевые работы базисом для флористических и таксономических исследований, Надежда Алексеевна ежегодно участвует в нескольких экспедициях. Идя впереди группы, она прокладывает маршрут по интересным в ботаническом плане местам, не показывая усталости и заряжая своей энергией 


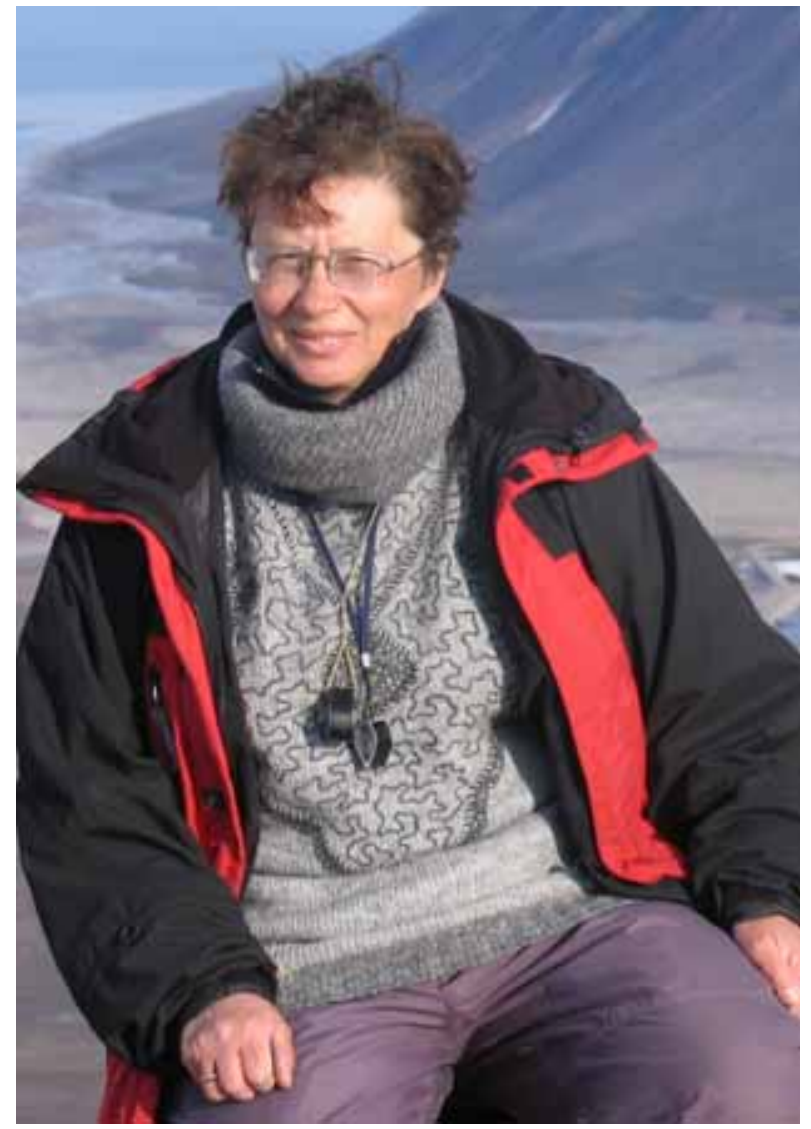

2008, Шпицберген, поселок Пирамида Svalbard (Spitzbergen), Pyramiden Settlement

groups of liverworts. She prepared the revisions of several genera of liverworts of Russia: Eremonotus, Tetralophozia, Iwatsukia, Anastrepta, Calycularia, Sauteria, order Pallaviciniales, and others. She described many new taxa for science both extant (Apotreubia hortoniae R.M. Schust. \& Konstant. ex Konstant., Jubula hutchinsiae subsp. caucasica Konstant. \& Vilnet, etc.) and fossil (Frullania ucrainica Konstant. \& Ignatov). Nadezhda proposed more than 60 new combinations, and most of them were accepted by the bryological community.

As the innovative leader in bryological science in Russia, Nadezhda started the first database of bryophyte collection in Kirovsk herbarium at the beginning of the nineties, when personal computers were exceptionally rare in Russia. This system is in constant use and has outstanding value in bryological researches until present. She was actively involved in applying GIS-technologies to bryology. Due to collaborated efforts and under her careful advice one of the most modern Cryptogamic Russian Information System has been developed (authors A. Melekhin and D. Davydov).

Despite constant difficulties with the financial support she organized the first molecular genetic laboratory in Russia dealing with liverworts. This laboratory works in constant collaboration with the laboratory of genosys- товарищей. Никогда не унывающая при возникновении проблем, будь то затянувшаяся непогода или неувязки с транспортом, Надежда Алексеевна умеет поднять настроение, минусы обратить в плюсы и организовать работу так, что даже в неблагоприятных погодных условиях эффективность работы всей экспедиции оказывается очень высокой. Даже при получении травм, которые в экспедициях может получить каждый полевик, Надежда Алексеевна стойко переносит боль, не показывая вида, и продолжает “через не могу” принимать участие в маршрутах или, если это невозможно, самостоятельно обследует участки, куда может добраться, отмахиваясь от уговоров остаться в палатке и подлечиться. А сколько раз ее общительность и умение расположить к себе незнакомых людей помогала получать помощь экспедиционным отрядам в трудных ситуациях! При этом Надежда Алексеевна обладает всеми необходимыми навыками походной жизни - умеет разжечь костер, приготовить на нем еду, обучить тонкостям сбора и сушки образцов. Общение с Надеждой Алексеевной во время экспедиций позволяет приобрести знания, привычки и опыт, полезные как молодежи, так и более зрелым научным сотрудникам.

В многочисленных поездках по Мурманской области, Кавказу, Сибири, Центральной России, Уралу, архипелагу Шпицберген ею собран обширный гербарный материал, проведены ценные наблюдения по экологии и распространению печеночников. Она многие годы работает в тесной связи со многими заповедниками России, среди них Лапландский, Кандалакшский, Кавказский, Тебердинский, Вишерский, “Басеги”, "Большая Кокшага", Керженский, Байкальский и др.

Надежда Алексеевна является первоклассным флористом. При этом при идентификации сборов она очень часто сталкивается с необходимостью таксономических монографических исследований. Ею обработан ряд групп для «Флоры России», что включает детальные описания, иллюстрации, анализ распространения и экологии входящих в них видов, в том числе: родов Marsupella, Eremonotus, Tetralophozia, Iwatsukia, Anastrepta, Calycularia, Sauteria, порядка Pallaviciniales и др. Ею описаны новые для науки таксоны как ныне живущих печеночников (Apotreubia hortoniae R.M. Schust. \& Konstant. ex Konstant., Jubula hutchinsiae subsp. caucasica Konstant. \& Vilnet, etc.), так и ископаемых (Frullania ucrainica Konstant. \& Ignatov). Она предложила более 60 новых комбинаций, большинство из которых были приняты бриологическим сообществом.

Н.А. Константинова вырастила целую плеяду активно и творчески работающих молодых научных сотрудников. В настоящее время она возглавляет в ПАБСИ научную школу криптогамной ботаники. Под ее руководством было успешно защищено 8 кандидатских диссертаций. Один из ее учеников, В.А. Бакалин, после защиты в 2008 г. докторской диссертации возглавил бриологическое направление на Дальнем Востоке и 


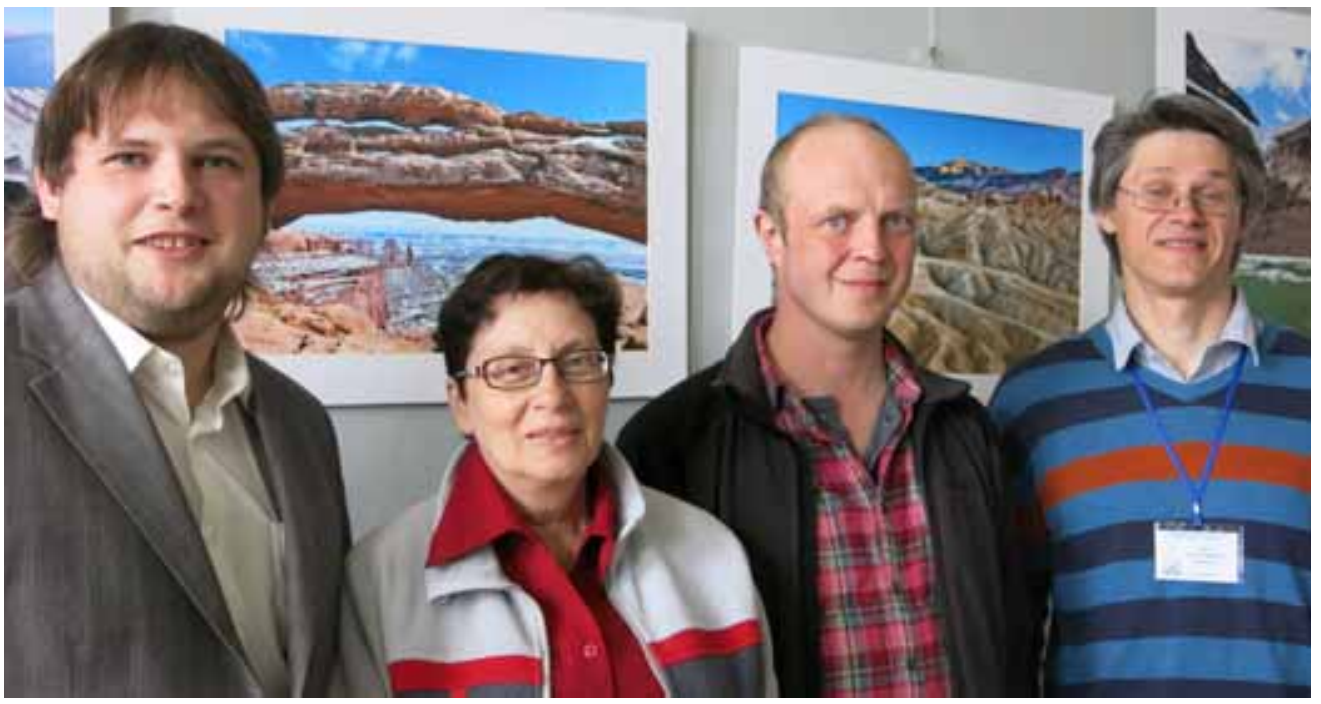

2015, Кировск, ПАБСИ

Н.А. Константинова с учениками (слева направо): Е.А. Боровичев, Н.А. Константинова, В.А. Бакалин Д.А. Давыдов 2015, Kirovsk, PolarAlpine Botanical Garden Institute N.A. Konstantinova with her students (left to right): E.A. Borovichev

N.A. Konstantinova, V.A. Bakalin, D.A. Davydov

tematics in the Institute of Physical and Chemical Biology of Moscow State University. As a result, the phylogeny of two notoriously difficult groups of liverworts (Jungermannianeae and Cephaloziineae) was evaluated, and several taxa new for science were described: one new family (Vilnet, Konstantinova \& Troitsky, 2011), several new genera (Konstantinova, Vilnet, 2009; Vilnet, Konstantinova \& Troitsky, 2010, 2012à), and numerous new species (Bakalin \& Vilnet, 2009, 2012; Vilnet, Borovichev \& Bakalin, 2014; Bakalin, Vilnet, Furuki \& Katagiri, 2014; Mamontov \& Vilnet, 2015).

Nadezhda is an effective teacher, who stimulated and encouraged a number of bryologists, lichenologists and algologists throughout Russia. Some of them were inspired at young age to start scientific investigations by communication with her.

One of her PhD students, Vadim Bakalin, defended a thesis to obtain the degree of Doctor of Science and now he is the head of the cryptogamic laboratory in Vladivostok Botanical Garden. Another student, Mikhael Dulin, conducts researches of liverworts in Syktyvkar, Komi Republic. Six PhD students, Nadezhda's graduates, are working in the Polar-Alpine Botanical Garden-Institute. Tatiana Drugova studies moss floras of urbanized areas, Anna Vilnet performs molecular and genomic analyses, Eugeny Borovichev investigates Marchantiales of Russia, Denis Davydov and Sergey Shalygin are dealing with Cyanobacteria, and Aleksey Melekhin studies lichens of Murmansk Province. Since 2009 Yury Mamontov joined the Konstantinova's research group, being involved in the Transbaikalian hepatic study.

The vital part of Nadezhda's activities is the management and organization of the Herbarium together with identification of unidentified collections. Commonly she spent evenings in the laboratory dealing with miscellaneous specimen sets from various areas. She organizes exchange of specimens with foreign herbaria to enrich the collection. The 'cryptogamic sector' of the Herbarium of Polar-Alpine Botanical Garden-Institute сейчас заведует лабораторией криптогамной биоты Ботанического сада-института ДВО РАН. Другой ученик, к.б.н. М.В. Дулин, успешно трудится в Институте биологии Коми НЦ Уральского отделения РАН. Шесть учеников Надежды Алексеевны, молодые кандидаты биологических наук, работают в ПАБСИ: Т.П. Другова исследует флоры мхов городов и поселков Мурманской области; А.А. Вильнет - одна из наиболее плодотворно работающих в мире молекулярных гепатикологов; Е.А. Боровичев изучал флору печеночников крупнейшего в Европе Лапландского заповедника и сейчас занимается исследованием порядка Marchantiales в России; Д.А. Давыдов изучает разнообразие сине-зеленых водорослей европейского сектора Арктики и Субарктики; С.С. Шалыгин, защитив диссертацию по сине-зеленым водорослям Лапландского заповедника, сейчас работает с культурами цианопрокариот в США; А.В. Мелехин исследует разнообразие лишайников Мурманской области. В 2009 г. на работу в ПАБСИ ее стараниями приглашен сотрудник Сургутского государственного университета, к.б.н. Ю.С. Мамонтов, изучающий печеночники Забайкалья. Однако, отчасти ее учениками чувствуют себя, наверное, все гепатикологи России и многие бриологи, в разное время посещавшие Мурманскую область и сотрудничавшие с Надеждой Алексеевной.

В своей научной работе Надежда Алексеевна значительное место отводит работе с гербарием и с еще не обработанными коллекциями. Часто вечерами ее можно застать в кабинете за определением образцов. Она ведет обширную переписку с зарубежными коллегами для установления научного обмена и пополнения бриологического гербария. Гербарий криптогамных растений лаборатории флоры и растительных ресурсов ПАБСИодин из крупнейших гербариев мохообразных России и одна из самых динамично развивающихся российских ботанических коллекций. Став в 1984 г. куратором этого гербария, Надежда Алексеевна установила контакты и обмен с важнейшими гербариями мира, в результате чего 


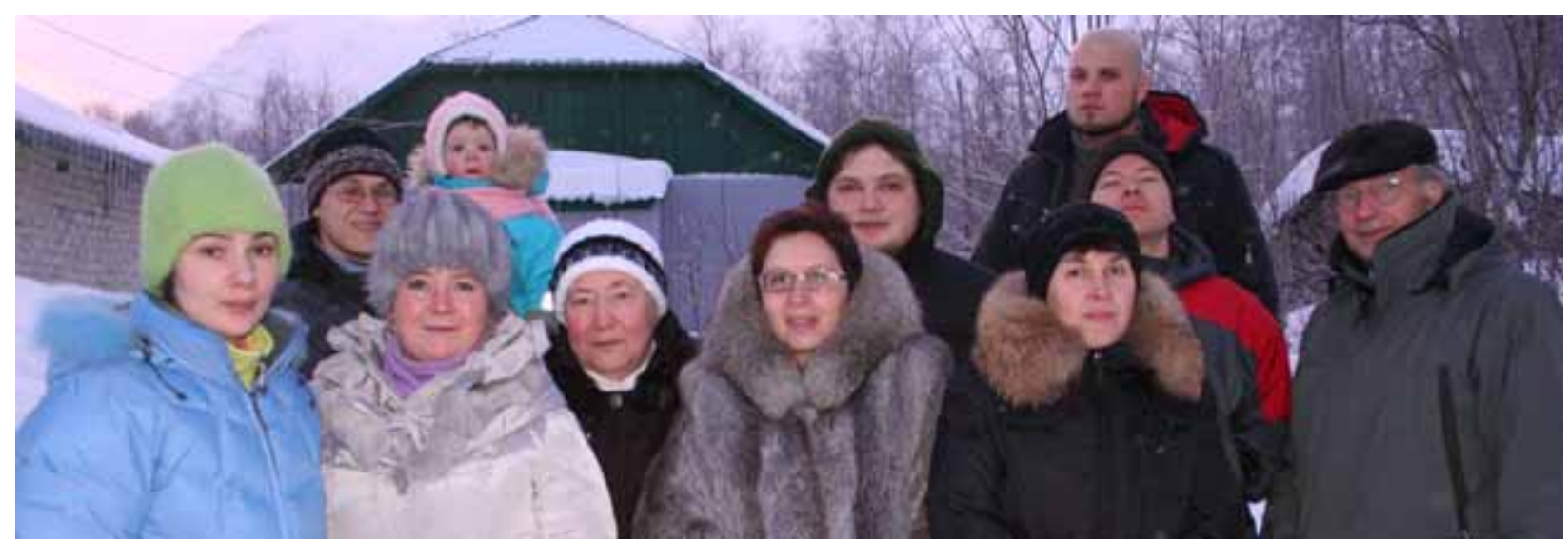

2009, Кировск: Сотрудники лаборатории флоры и растительных ресурсов ПАБСИ (слева направо): А.А. Вильнет, Д.А. Давыдов (с дочерью В.Д. Давыдовой), Т.П.Другова, В.А. Костина, Н.А. Константинова, Е.А. Боровичев, Н.Е. Королева, А.В. Мелехин, С.С. Шалыгин, А.Н. Савченко - 2009, Kirovsk: Staff of the Flora and Vegetation laboratory of the PolarAlpine Botanical Garden-Unstitute (left to right): A.A. Vilnet, D.A. Davydov (with daughter V.D. Davydova), T.P. Drugova, V.A. Kostina, N.A. Konstantinova, E.A. Borovichev, N.E. Koroleva, A.V. Melekhin, S.S. Shalygin, A.N. Savchenko.

is one of the largest in Russia (the collection of liverworts is the largest) and one of the most prosperous Herbaria in Russia. From the time when she was employed in 1984 as the curator of the herbarium, the bryophyte collection increased from 2500 to 45000 specimens. In 2004 the collection of cyanobacteria was started. The Herbarium publishes Hepaticae Rossicae Exsiccatae from 2003 onwards, and until now 250 specimens in ten fascicles were published.

Nadezhda is an excellent organizer of science research. Under her leadership the laboratory of flora and vegetation takes part in the study of ecosystems of the Svalbard Archipelago. Nadezhda contributed greatly to bryophyte conservation in Russia and in Murmansk Province. She took part in writing more than 20 regional Red Data Books. Some bryophyte species were included in the Red Data Book of European Bryophytes after her proposals. She was in the editorial board of Red Data Book of Murmansk Province (2003, 2014) and took part in the proposition and inventory of 15 special protection areas.

Nadezhda is a talented popularizor of science. Her lectures are always unique and exciting. She was the main inspirer of several valuable regional botanical guide books: "Botanical Excursion in Lovozero and Khibiny Mts." (2005) and "Nature monuments and sights of Murmansk Province" (2004, 2008).

The remarkable achievements of Nadezhda have been recognized and acknowledged by the scientific community and authorities. She is an expert of the council for nature conservation in international and European committees for nature protection, of the council for Red Data Book of Russia maintenance, International and British Bryological Societies, the Russian Botanical Society, she is member of the coordinating council for the compiling of the "Global checklist of hornworts and liverworts", member of the editorial board of the Russian bryological journal Arctoa, and the journal Botanica Pacifica. In her фонды гербария мохообразных ПАБСИ выросли с 2500 до 45000 образцов. В 2004 г. в его составе появилась коллекция цианобактерий. Надежда Алексеевна, продолжая традицию крупнейших бриологов, основала издание эксикат печеночников России, которое активно продолжает В.А. Бакалин. С 2003 г. уже вышли 10 выпусков.

Н.А. Константинова - талантливый организатор науки. Благодаря ее усилиям, с 2004 г проводятся исследования флоры, растительности и продукционных особенностей арктических экосистем на архипелаге Шпицберген. Собранный ею коллектив изучает бриофлору, лихенобиоту, разнообразие цианопрокариот, а также почвы различных районов архипелага, осуществляет эколого-физиологические эксперименты и мониторинговые наблюдения. Одним из промежуточных результатов этих исследований стала великолепно изданная книга «Флора и растительность побережья залива Грен-фьорд (архипелаг Шпицберген)» (2008), одним из редакторов которой была Надежда Алексеевна. Сейчас заканчивается подготовка иллюстрированного путеводителя по криптогамной биоте района поселка Пирамида.

Н.А. Константинова внесла огромный вклад в дело охраны природы. Она - автор видовых очерков печеночников более чем в 20 региональных Красных книгах. Предложенные ее виды вошли в Red Data Book of European Bryophytes (1995). Не оставляет без внимания она и Мурманскую область. Являясь ответственным редактором уже двух изданий Красной книги Мурманской области $(2003,2014)$ она курирует более $2 / 3$ внесенных в Красную книгу объектов - это растения, водоросли, грибы и лишайники. При деятельном участии Надежды Алексеевны спроектировано не менее 15 ООПТ в Мурманской области.

Надежда Алексеевна - увлечённый популяризатор науки. Ее интервью и выступления перед публикой это всегда захватывающее зрелище. Она была идей- 


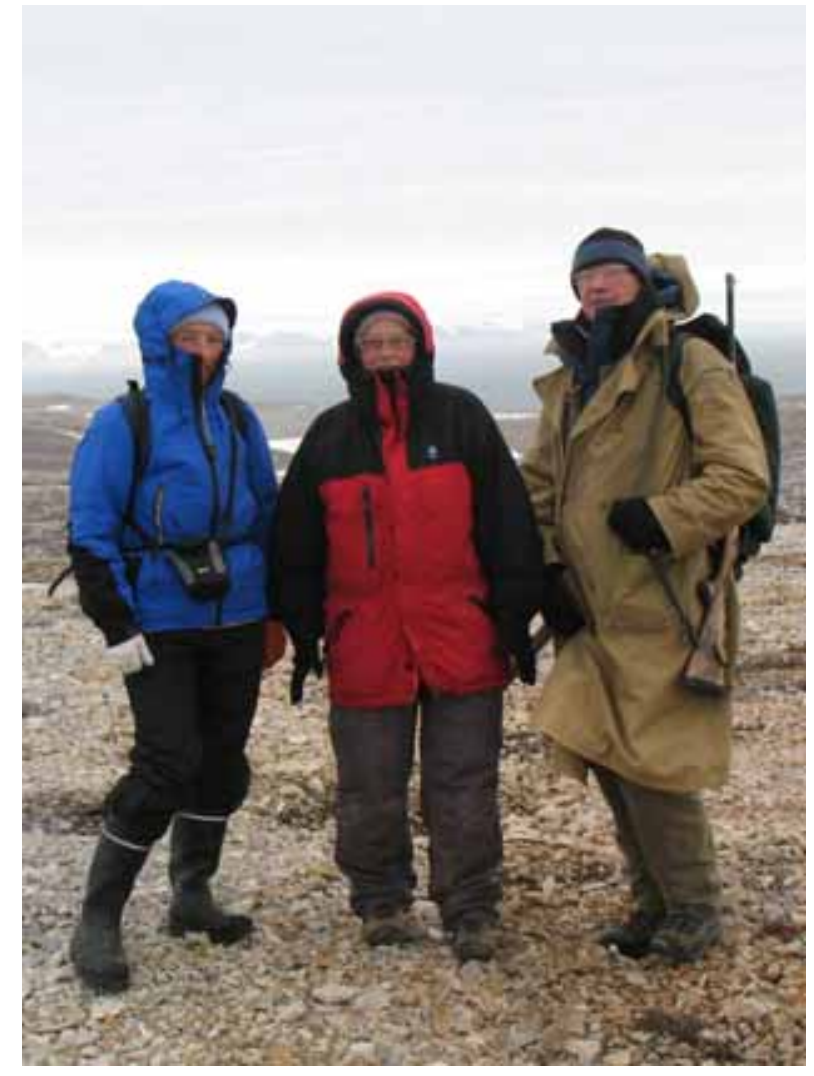

2007, Шпицберген, Северо-Восточная земля, залив Нордвика - Svalbard (Spitzbergen), Nordaustlandet, Nordvik Bay

Слева направо: О.А. Белкина, Н.А. Константинова, А.Н. Савченко - Left to right: O.A. Belkina, N.A. Konstantinova, A.N. Savchenko

honour is described new species, Jungermannia konstantinovae Bakalin \& Vilnet.

Nadezhda is not a hardhearted scientist who could not see anything but science. On the contrary, she is full of love to classical music, literature and art; plays piano and guitar. She is a hospitable housekeeper and doors of her modest home are always opened for her friends and colleagues coming to the Polar-Alpine Botanical Garden-Institute.

All who know Nadezhda always note her heartfelt generosity, cheerfulness and lady charm. Her great erudition, high cultural experience, and decency are indispensable virtues of Russian intelligentsia. She firmly defends basic principles of science, helps young researchers, and communicates with colleagues worldwide.

In the day of her jubilee we cordially congratulate Nadezhda, thank her for her kind attention and help to all of us and wish her to maintain her creative energy for many and many years more.

We wish you success in your research and love from your close ones, dear Nadezhda Alekseevna! ным вдохновителем подготовки и публикации научнопопулярных книг и брошюр о растениях и ценных ботанических территориях Мурманской области, таких, как “Ботанические экскурсии по Хибинским и Ловозерским горам" (2005), участвовала в написании книг из серии "Памятники природы и достопримечательности Мурманской области” (2004, 2008).

Надежда Алексеевна входит в совет Русского ботанического общества, Международного и Британского бриологических обществ, экспертного совета по сохранению видов Международного и Европейского обществ охраны природы, экспертных советов по Красной книге России и СНГ, авторского коллектива составителей мирового списка печеночников (“Global checklist of hornworts and liverworts"). Как член редколлегии принимает активное участие в издании журнала “Arctoa” с года его создания, входит в состав редакционного совета журнала "Botanica Pacifica". В честь Надежды Алексеевны описан новый для науки вид - Jungermannia konstantinovae Bakalin \& Vilnet.

Надежда Алексеевна не замыкается только на работе. Она прекрасно знает художественную литературу, очень любит музыку, театр, сама замечательно исполняет романсы и песни, играет на гитаре и пианино. Кроме неоспоримых научных заслуг, коллеги отмечают удивительную душевную щедрость, жизнерадостность и женское обаяние Надежды Алексеевны. Она радушная хозяйка, и двери ее скромного дома всегда открыты для друзей, близких и коллег. Её отличает широкая эрудиция, высокий культурный уровень, порядочность, что всегда было свойственно настоящему русскому интеллигенту. Надежде Алексеевне присуще еще одно качество - она активно привлекает в науку и в свою лабораторию людей, умеющих самоотверженно работать и любящих свое дело. Своей увлеченностью и высокой работоспособностью она побуждает и своих коллег трудиться с полной отдачей, повышать свои знания и квалификацию. Заслуживает уважения ее активная гражданская позиция, она последовательно и твердо пропагандирует и проводит в жизнь базовые принципы науки и научной методологии, поддерживает научные традиции ПАБСИ, развивает новые прогрессивные научные направления, осуществляет плодотворные контакты с мировым научным сообществом, поднимая тем самым авторитет российской науки.

Поздравляя Надежду Алексеевну, мы благодарим за ее внимание и помощь всем нам, а также желаем ей поддерживать высочайшую творческую активность еще много-много лет.

Здоровья Вам, счастья и любви близких и родных, дорогая Надежда Алексеевна - основы новых свершений и открытий!

Коллеги и друзья

Colleagues and friends 


\section{ПУБЛИКАЦИИ НАДЕЖДЫ АЛЕКСЕЕВНЫ КОНСТАНТИНОВОЙ

PUBLICATIONS OF NADEZHDA A. KONSTANTINOVA}

[KONSTANTINOVA, N.A.] КОНСТАНТИНОВА Н.А. 1975. Редкие и интересные таксоны печеночников из Хибинских гор. - [Rare and interesting liverworts taxa from Khibiny Mts.] В кн.: Флористические исследования и зеленое строительство на Кольском полуострове (ред. Раменская М.Л., Т.А. Koзуnеева) [In: Ramenskaya, M.L. \& T.A. Kozupeeva (eds.) Floristicheskie issledovaniya i zelyonoe stroitel 'stvo na Kol'skom Poluostrove] Anamumbl [Apatity]: 59-62.

[KONSTANTINOVA, N.A.] КОНСТАНТИНОВА Н.А. 1976. Роль мохообразных в горных тундрах Хибин. - [The role of the bryophytes in mountain tundras of Khibiny Mts.] $B$ кн.: Охрана среды и рациональное использование растительных ресурсов [In: Okhrana sredy i ratsional'noe ispol'zovanie rastitel'nykh resursov] Москва [Moscow]: 46-47.

[KONSTANTINOVA, N.A.] КОНСТАНТИНОВА Н.А. 1976. Печеночники Хибинских гор. - [Liverworts taxa of Khibiny Mts.] В кн.: Изучение растительных ресурсов Мурманской области (ред. Шляков P.H.) [In: Schljakov, R.N. (ed.) Izuchenie rastitel 'nykh resursov Murmanskoj oblasti] Anamumbl [Apatity]: 36-47.

[KONSTANTINOVA, N.A.] КОНСТАНТИНОВА Н.А. 1977. Печеночники верхних поясов Хибинских гор. - [Liverworts of the upper belts of the Khibiny Mts.] В кн.: Тезись докл. VII Всесоюзное совещание "Вопросы изучения и освоения флоры и растительности высокогорий” [In: VII Vsesoyuznoe soveshchanie "Voprosy izuchenia $i$ osvoeniya flory i rastitel 'nosti vysokogorij" $]$ Новосибирск [Novosibirsk]: $68-69$.

[KONSTANTINOVA, N.A.] КОНСТАНТИНОВА Н.А. 1978. К флоре печеночных мхов Хибинских гор. - [On liverworts flora of the Khibiny Mts.] Новости систематики низших растений [Novosti sistematiki nizshikh rastenij] 15: 231-233.

[KONSTANTINOVA, N.A.] КОНСТАНТИНОВА Н.А.1978. Редкий вид печеночника Sphenolobopsis pearsonii (Spruce) Schust. в Хибинских горах. - [Rare liverwort species Sphenolobopsis pearsonii (Spruce) Schust. in Khibiny Mts.] Ботанический журнал [Botanicheskij Zhurnal] 63(7): 1032-1035.

[KONSTANTINOVA, N.A.] КОНСТАНТИНОВА Н.А. 1979. Распространение видов печеночников по поясам в Хибинских горах. - [Distribution of liverworts in Khibiny Mt. belts] В кн.: Тезисы докл. VIII симпозиум "Биологические проблемы Севера" [In: VIII simpozium "Biologicheskie problemy Severa”] Anamumbl [Apatity]: 38-39.

[KONSTANTINOVA, N.A.] КОНСТАНТИНОВА Н.А. 1979. Таксономический анализ флоры печеночников Хибин. [Taxonomical analysis of liverworts flora of the Khibiny Mts.] В кн.: Тезисы докл. Проблемы изучения и использования в народном хозяйстве растений природной флоры [In: Problemy izucheniya i ispol 'zovania $v$ narodnom khozyajstve rastenij prirodnoj flory] Москва [Moscow]: 65-66.

[KONSTANTINOVA, N.A.] КОНСТАНТИНОВА Н.А. 1980. Основные синузии печеночников Хибин и их роль в растительном покрове. - [The main liverworts sinusia in
Khibiny Mts. and their role in vegetation] В кн.: Биологофлористические исследования в связи с охраной природы в Заполярье (ред. Шляков P.H.) [In: Schljakov, R.N. (ed.) Biologo-floristicheskie issledovaniya v svyazi s okhranoj prirody v Zapolyar'e] Anamumbl [Apatity]: 96-107.

[KONSTANTINOVA, N.A. \& A.P. TYRTYKOV] KOHCTAHТИНОВА Н.А., А.П. ТЫРТИКОВ. 1980. Растительность озерного района Центрального Ямала. - [Vegetation of lake district of Central Yamal] Научные доклады высшей школьы. Биологические науки [Nauchnye doklady vysshej shkoly. Biologicheskie nauki] 2: 76-82.

[KONSTANTINOVA, N.A.] КОНСТАНТИНОВА Н.А. 1980. Редкие печеночники Хибин и их охрана. - [Rare liverworts of the Khibiny Mts. and their protection] В кн.: Тезисы докл. IV Всесоюз. совещ. "Пути интенсификаиии сельского хозяйства Крайнего Севера" [In: IV Vsesoyuznoe soveshchanie "Puti intensifikatzsii khozyaistva Krainego Severa] Магадан [Magadan] 7: 90-92.

[KONSTANTINOVA, N.A.] КОНСТАНТИНОВА Н.A. 1981. К флоре печеночников Рыбачьего полуострова. - [On liverworts flora of the Rybachij Peninsula] В кн.: Тезисы докл. Бриолихенологические исследования высокогорных районов и севера СCCP [In: Briolihenologicheskie issledovaniya vysokogornykh rajonov i severa USSR] Anamumb [Apatity]: 43-44.

[SCHLJAKOV, R.N. \& N.A. KONSTANTINOVA] ШЛЯКOB Р.Н., Н.А. КОНСТАНТИНОВА. 1981. Бриологические исследования в Мурманской области. - [Bryological studies in Murmansk Region] В кн.: Развитие ботанических исследований на Кольском Севере (ред. Андреев Г.Н.) [In: Andreev, G.N. (ed.) Razvitie botanicheskikh issledovanij na Kol'skom severe] Anamumbl [Apatity]: 36-43.

[SCHLJAKOV, R.N. \& N.A. KONSTANTINOVA] ШЛЯКОВ Р.Н., Н.А. КОНСТАНТИНОВА. 1981. Таксономическая структура флоры мохообразных Мурманской области. [Taxonomical stucture of bryophyte flora of Murmansk Region] В кн.: Тезисы докл. Бриолихенологические исследования высокогорных районов и севера ССCP [In: Briolihenologicheskie issledovaniya vysokogornykh rajonov $i$ severa USSR] Anamumbl [Apatity]: 64-67.

[SCHLJAKOV, R.N. \& N.A. KONSTANTINOVA] ШЛЯКOB Р.Н., Н.А. КОНСТАНТИНОВА. 1982. Конспект флоры мохообразных Мурманской области. - [Synopsis of the Bryophytes of the Murmansk Region] Anamumbl [Apatity], $222 \mathrm{pp}$.

[ANTONOVA, I.M. \& N.A. KONSTANTINOVA] AHTOHOBA И.М., Н.А. КОНСТАНТИНОВА. 1983. Совещание "Бриолихенологические исследования высокогорных районов Севера СССР". - [Meeting "Bryolichenological studies of high-mountain districts of the USSR North"] Ботанический журнал [Botanicheskij Zhurnal] 68(6): 854-856.

[KONSTANTINOVA, N.A.] КОНСТАНТИНОВА Н.А. 1983. Печеночники полуостровов Рыбачьего и Среднего Мурманской области. - [Liverworts of the Rybachij and Srednij Peninsulas (Murmansk Region)] Новости систематики низших растений [Novosti sistematiki nizshikh rastenij] 20: 194-200.

[KONSTANTINOVA, N.A.] КОНСТАНТИНОВА Н.А. 1984. Гербарий. Мохообразные. - [Herbarium. Bryophytes] В кн.: Полярно-альпийский ботанический сад. Путеводитель 
(ред. Козупеева T.A.) [In: Kozupeeva, T.A. (ed.) Polar-alpine Botanical Garden. Guide-book] Ленинград [Leningrad]: 76-77.

[KONSTANTINOVA, N.A.] КОНСТАНТИНОВА Н.A. 1984. Флористическая насыщенность в сообществах горных тундр Хибин. - [Alpha diversity in tundra plant communities in Khibiny Mts.] В кн.: Тезисы докл. Растительный покров субарктических высокогорий и проблема арктоальпийских флористических связей» [In: Rastitel 'nyj pokrov subarcticheskikh vysokogorij i problema arktoal'pijskikh floristicheskikh svyazey] Anamumbl [Apatity]: 61-62.

[KONSTANTINOVA, N.A.] КОНСТАНТИНОВА Н.А. 1985. Интересные находки печеночных мхов в Ловозерских горах (Мурманская область). - [Intresting findings of liverworts in Lovozero Mts. (Murmansk Region)] Hовостu систематики низших растений [Novosti sistematiki nizshikh rastenij] 22: 229-231.

[KONSTANTINOVA, N.A.] КОНСТАНТИНОВА Н.A. 1986. Печеночники восточных склонов Ловозерских гор к северу от залива Мотлухт. - [Liverworts of eastern slope of the Lovozero Mts. northward from Motlukt Bay] $B$ кн.: Почвенно-ботанические исследования в Кольской Субарктике (ред. Андреев Г.H.) [In: Andreev, G.N. (ed.) Pochvenno-botanicheskie issledovaniya $v$ Kol'skoj Subarktike] Anamumbl [Apatity]: 3-9.

[KONSTANTINOVA, N.A. \& A.Yu. LIKHACHEV] KOHСТАНТИНОВА Н.А., А.Ю. ЛИХАЧЕВ. 1986. Мохообразные территории Полярно-альпийского ботанического сада. - [Bryophytes of the territory of Polar-alpine Botanical Garden] В кн.: Бриолихенологические исследования в СССР (ред. Шляков P.H.) [In: Schljakov, R.N. (ed.) Bryolichenological studies in the USSR] Anamumbl [Apatity]: 8-19.

[BELKINA, O.A. \& N.A. KONSTANTINOVA] БЕЛКИНА О.А., Н.А. КОНСТАНТИНОВА. 1987. Мохообразные Хибино-Ловозерского флористического района. - [Bryophytes of Khibiny-Lovozero floristic district] Anamumbl [Apatity], $46 \mathrm{pp}$.

[KONSTANTINOVA, N.A.] КОНСТАНТИНОВА Н.A. 1987. Печеночники Ловозерских гор (Мурманская область). [Liverworts of the Lovozerskie Mts. (Murmansk Region)] Новости систематики низших растений [Novosti sistematiki nizshikh rastenij] 24: 218-225.

[KONSTANTINOVA, N.A. \& A.Yu. LIKHACHEV] KOHСТАНТИНОВА Н.А., А.Ю. ЛИХАЧЕВ. 1987. Мохообразные территории Полярно-альпийского ботанического сада. - [Bryophytes of the territory of Polar-alpine Botanical Garden] Anamumbl [Apatity], 25 pp.

[SCHLJAKOV, R.N., N.A. KONSTANTINOVA, O.A. BELKINA \& A.Yu. LIKHACHEV] ШЛЯКОВ P.Н., Н.A. КОНСТАНТИНОВА, О.А. БЕЛКИНА, А.Ю. ЛИХАЧЕВ. 1987. Изучение флоры мохообразных Мурманской области (состояние и перспективы). - [The study of bryophyte flora of Murmansk Region (curent state and prospects)] $B \kappa н$.: Ботанические исследования за полярным кругом (ред. Лукьянова Л.M.) [In: Luk'yanova, L.M. (ed.) Botanicheskie issledovaniya za polyarnym krugom] Ленинград, Наука [Leningrad, Nauka]: 42-47.

ANDREEV, G.N. \& N.A. KONSTANTINOVA. 1988. A Botanical Garden within the Arctic Circle. - Taxon Billetin of Bryology XXVI 37(4): 921-925.
KONSTANTINOVA, N.A. 1988. Addition to the Hepatic flora of the Murmansk Region (USSR). - In: Abstracts of Sixth Meeting of the Central and East European Bryological Working group: 23.

[KONSTANTINOVA, N.A.] КОНСТАНТИНОВА Н.А. 1988. Таксономическая структура флоры печеночников ХибиноЛовозерского района (Мурманская область). - [Тахоnomical structure of liverworts flora of Khibiny-Lovozero District] В кн.: Тезисы докл. Актуальные вопросы ботаники в CCCP. VIII делегат. съезд ВБО [In: Aktualnye voprosy botaniki v SSSR. VIII delegatskij s'ezd VВO] Aлма-Ama [AlmaAta]: 104.

[KONSTANTINOVA, N.A. \& O.A. BELKINA] KOHCTAHТИНОВА Н.А., О.А.БЕЛКИНА. 1988. Мохообразные древесных субстратов в Ловозерских горах. - [Bryophytes on wood in Lovozerskie Mts.] Бюллетень Московского общества испытателей природы. Отдел биологический [Bulletin of Moscow Society of Naturalists. Biology Division] 93(4): 80-88.

KONSTANTINOVA, N.A. 1989. Addition to the Hepatic Flora of the Murmansk Region (USSR). - In: Proceedings of the Sixth Meeting of the Central and East European Bryological Working Group (CEBWG), Lublice, Czechoslovakia, 12th through 16th September 1988. Publ.: Botanical Inst. of the Czechoslovak Academy of Sciences, Pruhonice: $54-65$

[KONSTANTINOVA, N.A.] КОНСТАНТИНОВА Н.А. 1989. Бриофлористическое изучение Мурманской области, состояние, перспективы, проблемы. - [The study of bryophyte flora of Murmansk Region: current state, prospects and problems] В кн.: Тезисы докл. Всесоюзная конференция "Проблемы комплексного использования nриродных ресурсов Кольского полуострова" [In: Vsesoyuznaya konferentsia "Problemy komplesnogo ispol 'zovaniya prirodnykh resursov Kol 'skogo poluostrova"] Anamumbl [Apatity]: 95-96.

[KONSTANTINOVA, N.A.] КОНСТАНТИНОВА Н.А. 1989. Особенности таксономической структуры и сравнительная характеристика некоторых флор печеночников Севера. - [Peculiarities of taxonomic structure and comparative characteristics of some liverwort floras of the North] $B$ кн.: Проблемы бриологии в СССР [In: Problemy briologii v SSSR] Ленинград, Наука [Leningrad, Nauka]: 126-142.

[KONSTANTINOVA, N.A., O.A. BELKINA, A.Yu. LIKHACHEV, \& R.N. SCHLJAKOV] КОНСТАНТИНОВA H.A., О.А. БЕЛКИНА, А.Ю. ЛИХАЧЕВ, Р.Н. ШЛЯКОВ. 1989. Эксикаты мохообразных Мурманской области. Вып. І. [Bryophyta Murmanica Exciccatae. Fasc. I.] Anamumbl [Apatity], $25 \mathrm{pp}$.

AFONINA, O.M. \& N.A. KONSTANTINOVA. 1990. Current bryofloristic exploration of the North of the USSR. - In: Schljakov, R.N. (ed.) Abstracts of the Seventh Meeting of the Central and East European Bryological Working Group. Kirovsk-Apatity, 25-30 June 1990. Apatity, Acad. Sci. USSR, Kola Sci. Center, Polar-Alpine Bot. Garden: 4-5.

[AFONINA, O.M., N.A. KONSTANTINOVA \& I.V. CZERNYADJEVA] АФОНИНА О.М., Н.А. КОНСТАНТИНОВА, И.В. ЧЕРНЯДЬЕВА. 1990. Каталог литературы по мохообразным, опубликованной в СССР. 1986-1989. - [Catalogue of literature on bryophytes published in the USSR. 
1986-1989]. Anатиты, АН СССР, КНЦ, Полярно-Альп. Бom. Cad [Apatity, Akad. Sci. USSR, Kola Sci. Centre, Polar-Alpine Bot. Garden]: 1-51.

[ANDREEV, G.N., O.A. BELKINA, N.A. KONSTANTINOVA, V.A. KOSTINA, A.Yu. LIKHACHEV \& A.N. SAVCHЕNКО] АНДРЕЕВ Г.Н., О.А. БЕЛКИНА, Н.А. КОНСТАНТИНОВА, В.А. КОСТИНА, А.Ю. ЛИХАЧЕВ, А.Н. САВЧЕНКО. 1990. Путеводитель экскурсий по Хибинским горам. - [Excursion Guide on Khibiny Mountains] Anamumbl [Apatity], $52 \mathrm{pp}$

[KONSTANTINOVA, N.A.] КОНСТАНТИНОВА Н.А. 1990. К флоре печеночников севера Архангельской области (по сборам Ф.И. Рупрехта, 1841 г.). - [То the liverwort flora of the North of the Arkhangelsk Region (on the basis of F.I. Ruprekht's collection)] В кн.: Ботанические исследования за Полярным Кругом (ред. Лукьянова Л.M.) [In: Luk'yanova, L.M. (ed.) Botanical Investigations Within the Arctic Circle] Кировск, изд-во Кольского филиала АН СССР [Kirovsk, izdatel'stvo Kol'skogo filiala Akad. Nauk SSSR]: 92-97.

[KONSTANTINOVA, N.A.] КОНСТАНТИНОВА Н.А. 1990. Мохообразные, печеночники. - [Bryophytes, liverworts] $B$ кн.: Редкие и нуждаюшиеся в охране растения и животные Мурманской области (ред. Андреев Г.Н., О.А. Макарова) [In: Andrejev, G.N. \& O.A. Makarova (eds.) Redkie $i$ nuzhdayushsiesya $v$ okhrane rasteniya i zhivotnye Murmanskoj oblasti] Мурманск [Murmansk]: 14-19.

KONSTANTINOVA, N.A. 1990. Die Lebermoos-Flora der Lovsee-Berge (Lovozerskie Gory). - Feddes Repert. 101(56): $311-313$

[KONSTANTINOVA, N.A.] КОНСТАНТИНОВА Н.А. 1990. Новые находки редких видов печеночников из Мурманской области (северо-запад CCCP). - [New findings of rare liverworts from the Murmansk Region (north-west of the USSR)] Ботанический журнал [Botanicheskij Zhurnal] 75(9): 1306-1308.

KONSTANTINOVA, N.A. \& A.Yu. LIKHACHEV. 1990. Bryophytes of the Olenii Island (the Kandalaksha Bay of White Sea). - In: Schljakov, R.N. (ed.) Abstracts of the Seventh Meeting of the Central and East European Bryological Working Group. Kirovsk-Apatity, 25-30 June 1990. Apatity, Acad. Sci. USSR, Kola Sci. Center, Polar-Alpine Bot. Garden: 36.

[BELKINA, O.A., N.A. KONSTANTINOVA \& V.A. KOSTINA] БЕЛКИНА О.А., Н.А. КОНСТАНТИНОВА, В.А. КОСТИНА. 1991. Флора высших растений Ловозерских гор. Мохообразные и сосудистые растения. - [Flora of higher plants of Lovozerskie Mountains. Bryophytes and vascular plants] СПб., Наука [St.-Petersburg, Nauka]: 206 pp.

[KONSTANTINOVA, N.A., O.A. BELKINA \& A.Yu. LIKHACHEV] КОНСТАНТИНОВА Н.А., О.А. БЕЛКИНА, А.Ю. ЛИХАЧЕВ. 1991. Редкие мохообразные и их охрана в Мурманской области (северо-запад CCCP). - [Rare bryophytes and their protection in Murmansk Region (north-west of the USSR)] В кн.: Тезисы докл. Бриология в СССР, ее достижения и перспективы [In: Briologia v SSSR, eе dostizheniya i perspektivy] Львов [L'vov]: 107-112.

[KONSTANTINOVA, N.A.] КОНСТАНТИНОВА Н.А. 1992. Флора печеночников Кандалакшского заповедника (печеночники островов и побережья Порьей губы Белого моря). - [Liverwort flora of the Kandalaksha State Nature Reserve (liverworts of the islands and seashore of the Por'ya Bay of the White Sea)] В кн.: Тезисы докл. Проблемы оптимизации и использования растительности и растительных ресурсов на Европейском севере [In: Abstracts: Problemy optimizacii $i$ ispol'zovaniya rastitel 'nosti $i$ rastitel'nykh resursov na Evropejskom Severe] Архангельск [Arkhangelsk]: 16-17.

KONSTANTINOVA, N.A. 1992. Protection of bryophytes in the Murmansk Region. - Biological Conservation 59(2-3): 191-197.

KONSTANTINOVA, N.A., A.D. POTEMKIN \& R.N. SCHLJAKOV. 1992. Check-list of the Hepaticae and Anthocerotae of the former USSR. - Arctoa 1: 87-127.

[KONSTANTINOVA, N.A., A.Yu. LIKHACHEV \& O.A. BELКINA] КОНСТАНТИНОВА Н.А., А.Ю. ЛИХАЧЕВ, О.А. БЕЛКИНА. 1993. Дополнения и уточнения к "Конспекту флоры мохообразных Мурманской области”. - [Additions and refinements to "Synopsis of the Bryophytes of the Murmansk Region"] В кн.: Флористические и геоботанические исследования в Мурманской области (ред. Константинова H.A.) [In: Konstantinova, N.A. (ed.) Floristicheskie $i$ geobotanicheskie issledovaniya v Murmanskoj oblasti] Anamumbl [Apatity]: 6-44.

[KONSTANTINOVA, N.A., A.Yu. LIKHACHEV, O.A. BELKINA \& R.N. SCHLJAKOV] КОНСТАНТИНОВA H.A., А.Ю. ЛИХАЧЕВ, О.А. БЕЛКИНА, Р.Н. ШЛЯКОВ. 1993. Эксикаты мохообразных Мурманской области. Вып. II. [Bryophyta Murmanica Exciccatae. Fasc. II] Anamumbl $[$ Apatity], $22 \mathrm{pp}$.

KONSTANTINOVA, N.A., O.A. BELKINA \& A.Yu. LIKHACHEV. 1994. On the conservation of Kutsa area (South-West of Murmansk Region, Russia). - In: Conservation of Bryophytes in Europe. Means and Measures. Zuerich: 22.

KONSTANTINOVA, N.A., O.A. BELKINA \& A. Yu. LIKHACHEV. 1994. Towards a Red Data Book of Eastern Fennoscandia. - In: Conservation of Bryophytes in Europe. Means and Measures. Zuerich: 9.

[KONSTANTINOVA, N.A. \& V.B. KUVAEV] KOHCTAHТИНОВА Н.А., В.Б. КУВАЕВ. 1994. Класс Hераticae (Неpaticopsida) - Печеночники. - [Hepaticae] $В$ кн.: Куваев В.Б., А.Д. Кожевникова, С.В. Гудошников и др. Растительный покров острова Сибирякова. Опыт комплексного флористического и геоботанического исследования [In: Kuvaev, V.B., A.D. Kozhevnikova, S.V. Gudoshnikov et al. Rastitel'nyj pokrov ostrova Sibiryakova. Opyt kompleksnogo floristicheskogo i geobotanicheskogo issledovaniya] Москва [Moscow]: 27-30.

KONSTANTINOVA, N.A. \& A.D. POTEMKIN. 1994. Rare hepatics of the Russian Arctic and their protection. - In: Conservation of Bryophytes in Europe. Means and Measures. Zuerich: 9.

KONSTANTINOVA, N.A. \& A.D. POTEMKIN. 1994. Studies on Scapania sphaerifera (Hepaticae). - Annales Botanici Fennici 31: 121-126.

KONSTANTINOVA, N.A. \& A.N. VASILJEV. 1994. On the hepatic flora of Sayan Mountains (South Siberia). - Arctoa 3: $123-132$.

POTEMKIN, A.D. \& N.A. KONSTANTINOVA. 1994. First steps to liverwort conservation in the Russian Arctic. - In: Conservation of Bryophytes in Europe. Means and Measures. Zürich: 12. 
BELKINA, O.A., O.A. DRUZHININA, N.A. KONSTANTINOVA \& A.Yu. LIKHACHEV. 1995. Russia. - In: Hodgetts, N.G. (ed.) Red Data Book of European Bryophytes. Trondheim: 269-271.

KONSTANTINOVA, N.A. 1995. The genus Marsupella Dum. (Hepaticae) in the Russian Arctic: taxonomic diversity, distribution, peculiarities of reproduction. $-B к н .:$ Тез. докл. Проблемы изучения биологического разнообразия водорослей, грибов и мохообразных Арктики [In: Problemy izucheniya biologicheskogo raznoobraziya vodoroslej, gribov i mokhoobraznykh Arktiki] Санкт-Петербург [St.Petersburg]: 61-62.

[KONSTANTINOVA, N.A. \& I.V. CZERNJADIEVA] KOHСТАНТИНОВА Н.А., И.В. ЧЕРНЯДЬЕВА. 1995. Печеночники среднего течения реки Собь (Полярный Урал). - [Hepatics of the middle course of Sob' River (Polar Ural)] Новости систематики низших растений [Novosti sistematiki nizshikh rastenij] 30: 110-121.

POTEMKIN, A.D. \& N.A. KONSTANTINOVA. 1995. Rare liverworts of the Russian Arctic - a preliminary list and direction for future research. - Helvetia 18: 43-50.

SCHUSTER, R.M. \& N.A. KONSTANTINOVA. 1995. Studies on Treubiales. I. On Apotreubia Hatt. et al. and A. hortonae Schust. \& Konstantinova, sp.n. - Journal of the Hattori Botanical Laboratory 78: 41-61.

[KONSTANTINOVA, N.A.] КОНСТАНТИНОВА Н.A. 1996. Новые для Мурманской области и редкие печеночники с территории Кандалакшского заповедника (Северозапад России). - [New for Murmansk Region and rare liverworts of Kandalaksha Nature Reserve (North-West Russia)] Ботанический журнал [Botanicheskij Zhurnal] 81(8): 116-123.

KONSTANTINOVA, N.A. \& A.D. POTEMKIN. 1996. Liverworts of the Russian Arctic: an annotated checklist and bibliography. - Arctoa 6: 125-150

SCHUSTER, R.M. \& N.A. KONSTANTINOVA. 1996. Studies on the distribution of critical arctic/subarctic Hepaticae with special reference to taxa found in Russia. - Lindbergia 21: $26-48$

[KONSTANTINOVA, N.A.] КОНСТАНТИНОВА Н.А. 1997. Печеночники Кандалакшского заповедника (острова и побережье Кандалакшского залива Белого моря). - [Liverworts of the Kandalaksha State Nature Reserve (islands and the coast of the Kandalaksha Bay of the White Sea)] Anaтиты, Кольский научный центр РАН [Apatity, Kola Science Centre RAS]: 1-46.

[KONSTANTINOVA, N.A. \& A.N. SAVCHENKO] KOHСТАНТИНОВА Н.А., А.Н. САВЧЕНКО. 1997. База данных “Гербарий мохообразных Мурманской области". - [The database "Bryophyte Herbarium of Murmansk Region"] $B$ кн.: Компьютерные базы данных в ботанических исследованиях (ред. Гельтаман Д.В., Ю.Р. Росков) [In: Geltman, D.V. \& Yu.R.Roskov (eds.) Computer databases in botanical Research] Санкт-Петербург, БИН РАН [Sankt-Petersburg, Komarov' Bot. Inst., RAS]: 38-39.

[SAVCHENKO, A.N. \& N.A. KONSTANTINOVA] CABYEHКО А.Н., Н.А. КОНСТАНТИНОВА. 1997. Бриологические компьютерные базы данных в Полярно-альпийском ботаническом саду. - [Bryological databases in Polar-alpine Botanical Garden] В кн.: Компьютерные базы данных в ботанических исследованиях (ред. Гельтман Д.В., Ю.Р. Росков) [In: Geltman, D.V.\& Yu.R. Roskov (eds.) Computer databases in botanical Research] Санкт-Петербург, БИН PAH [Sankt-Petersburg, Komarov' Bot. Inst., RAS]: 44.

[KONSTANTINOVA, N.A.] КОНСТАНТИНОВА Н.А. 1998 Анализ поясно-зонального распределения печеночников в Мурманской области. - [Analysis of zonal distribution of Hepaticae in Murmansk Region (European Russia)] $B$ кн.: Проблемы ботаники на рубеже $X X-X X I$ веков. Тез. докл., представленных II(X) съезду Русского ботанического общества (26-29 мая 1998 г., Санкт-Петербург). Т. 2 [In: Problemy botaniki na rubezhe XX-XXI vekov. Abstr. II $(X)$ Congr. Russ. Bot. Soc. (26-29 May, 1998, St.-Petersburg). Vol. 2.] СПб, БИН РАН [St.-Petersburg, Komarov Bot. Inst., RAS]: $134-135$

[KONSTANTINOVA, N.A.] КОНСТАНТИНОВА Н.А. 1998. На пути к созданию сводки “Флора печеночников России”. - [Towards "Liverwort Flora of Russia"] В кн.: Проблемы ботаники на рубеже XX-XXI веков. Тез. докл., представленных II(X) съезду Русского ботанического общества (26-29 мая 1998 2., Санкт-Петербург). T. 2 [In: Problemy botaniki na rubezhe $X X-X X I$ vekov. Abstr. II $(X)$ Congr. Russ. Bot. Soc. (26-29 May, 1998, St.-Petersburg). Vol. 2.] СПб, БИН РАН [St.-Petersburg, Komarov Bot. Inst., RAS]: 135 .

KONSTANTINOVA, N.A. 1998. Liverworts, Hepaticopsida (MUR). - In: Kotiranta, H., P. Uotila, S. Sulkava \& S.-L. Peltonen (eds.) Red Data Book of East Fennoscandia. Ministry of the Environment Institute \& Botanical Museum, Finnish Museum of Natural History, Helsinki: 133-136.

[KONSTANTINOVA, N.A.] КОНСТАНТИНОВА Н.А. 1998. Флора печеночников Кандалакшского заповедника (острова и побережье Кандалакшского залива Белого моря). - [The liverwort flora of the Kandalaksha State Nature Reserve (islands and the coast of the Kandalaksha Bay of the White Sea)] Ботанический журнал [Botanicheskij Zhurnal] 83 (2): 25-40.

[KONSTANTINOVA, N.A., O.A. BELKINA, A.Yu. LIKHACHEV \& R.N. SCHLJAKOV] КОНСТАНТИНОВA H.A., О.А. БЕЛКИНА, А.Ю. ЛИХАЧЕВ, Р.Н. ШЛЯКОВ. 1998. Эксикаты мохообразных Мурманской области (Россия). Вып. III. - [Bryophyta Murmanica Exsiccata (Russia). Fasc. III] Anamumbl [Apatity]: 34 pp.

[KONSTANTINOVA, N.A. \& V.R. FILIN] КОНСТАНТИНОВА Н.А., В.Р. ФИЛИН. 1998. Печеночники низовьев реки Лена (Восточная Сибирь). - [Liverworts of the Lower Lena River (East Siberia)] Arctoa 7: 69-78.

LAAKA-LINDBERG, S. \& N.A. KONSTANTINOVA. 1998 Porella cordaena. - In: Kotiranta, H., P. Uotila, S. Sulkava \& S.-L.Peltonen (eds.) Red Data Book of East Fennoscandia. Ministry of the Environment Institute \& Botanical Museum Finnish Museum of Natural History, Helsinki: 138-139.

[KONSTANTINOVA, N.A.] КОНСТАНТИНОВА Н.А. 1999. Зонально-поясное распределение печеночников в Мурманской области. - [Liverworts of different zones and mountain belts in Murmansk Region] В кн: Флора и растительность Мурманской области (ред. Константинова Н.А.) [In: Konstantinova, N.A. (ed.) Flora i rastitel'nost' Murmanskoj oblasti] Anaтиты, Кольский научный иентр РАН [Apatity, Kola Sci. Centre RAS]: 124-148. 
[KONSTANTINOVA, N.A.] КОНСТАНТИНОВА Н.А. 1999. Памяти Романа Николаевича Шлякова (1912-1999). [Roman Nikolaevich Schljakov (1912-1999)] Arctoa 8: 89-100.

[KONSTANTINOVA, N.A.] КОНСТАНТИНОВА Н.А. 1999. Печеночники болот Мурманской области (северо-запад России). - [Mire liverworts of the Murmansk Region (NorthWest of Russia)] Ботанический журнал [Botanicheskij Zhurnal] 84(8): 60-68.

KONSTANTINOVA, N.A. 1999. Hepatics of the Anthropogenic Habitats of the Murmansk Region. - В кн.: Тез. докл.: Биологические основы изучения, освоения и охраны животного и растительного мира, почвенного покрова Восточной Фенноскандии [In: Abstracts: Biologicheskie osnovy izucheniya, osvoeniya i okhrany zhivotnogo i rastitel nogo mira, pochvennogo pokrova Vostochnoj Fennoskandii] Петрозаводск [Petrozavodsk]: 62.

KONSTANTINOVA, N.A. 1999. Rare Hepatics of Murmansk Region, North-West Russia. - В кн.: Тез. докл.: Биологические основы изучения, освоения и охраны животного и растительного мира, почвенного покрова Восточной Фенноскандии. [In: Abstracts: Biologicheskie osnovy izucheniya, osvoeniya i okhrany zhivotnogo $i$ rastitel 'nogo mira, pochvennogo pokrova Vostochnoj Fennoskandii] Петрозаводск [Petrozavodsk]: 61- 62.

[KONSTANTINOVA, N.A.] КОНСТАНТИНОВА Н.A. 2000. Анализ ареалов печеночников севера Голарктики. - [Distribution paterns of the North Holarctic hepatics] Arctoa 9: 29-94.

[KONSTANTINOVA, N.A.] КОНСТАНТИНОВА Н.А. 2000. Место Российской бриологии в современной науке и перспективы развития в начале третьего тысячелетия. - [Current state and perspectives of the Russian bryology in early $3 \mathrm{~d}$ millenium] В кн.: Микология и криптогамная ботаника в России: традиции и современность. Тр. междунар. конф., посвященной 100летию организации исследований по микологии и криптогамной ботанике в Ботаническом ин-те им. В. Л. Комарова РАН (Санкт-Петербург, 24-28 апреля, 2000 2.) [In: Mikologia i kriptogamnaya botanika v Rossii: traditsii i sovremennost' (Proc. konf., St-Petersburg, 2428 April, 2000)] СПб, БИН РАН [St.-Petersburg, Komarov' Bot. Inst. RAS]: 486-488.

[KONSTANTINOVA, N.A.] КОНСТАНТИНОВА Н.А. 2000. О географических элементах печеночников севера Голарктики. - [About geographical elements of liverworts of North Golarctic] В кн.: Микология и криптогамная ботаника в России: традици и современность. Тр. междунар. конф., посвященной 100-летию организации исследований по микологии и криптогамной ботанике в Ботаническом инте им. В. Л. Комарова РАН (Санкт-Петербург, 24-28 апреля, 2000 г.) [In: Mikologia i kriptogamnaya botanika $v$ Rossii: traditsii i sovremennost' (Proc. konf., St-Peterbsurg, 24-28 April, 2000)] СПб, БИН РАН [St.-Petersburg, Komarov' Bot. Inst. RAS]: 510-512.

[KONSTANTINOVA, N.A.] КОНСТАНТИНОВА Н.А. 2000. Редкие печеночники (Нераticae) Мурманской области и подходы к их охране. - [Rare liverworts (Hepaticae) of the Murmansk Region and some approaches to their protection] Ботанический журнал [Botanicheskij Zhurnal] 85(10): 122-135.
[KONSTANTINOVA, N.A.] КОНСТАНТИНОВА, Н.A. 2000. Печеночники болот Мурманской области и их охрана. [Liverworts of bogs in Murmansk Region and their conservation] В кн.: Сохранение биологического разнообразия Фенноскандии. Международная конференция, Петрозаводск, 30 марта - 2 апреля, 2000 г. [In: Conservation of biological diversity in Fennoscandia. The Book of Abstracts. International conference, Russia, Petrozavodsk, March 30 April 2, 2000.] Петрозаводск [Petrozavodsk, 2000]: 48-49.

[BAKALIN, V.A., N.A. KONSTANTINOVA \& G.V. ZHELEZNOVA] БАКАЛИН В.А., Н.А. КОНСТАНТИНОВА, Г.В. ЖЕЛЕЗНОВА. 2001. К флоре печеночников Северного Урала (Республика Коми). - [On the liverwort flora of Northern Urals (Komi Republic)] В кн.: Ботанические исследования на охраняемых природных территориях европейского северо-востока. Тр. Коми науч. иеетра УрО PAH, № 165 [In: Botanicheskie issledovaniya na ohranyaemyh territoriyah evropejskogo severo-vostoka. Trudy Komi nauchnogo centra UrO RAN, No. 165] Cыктывкар [Syktyvkar]: 208-216.

[KONSTANTINOVA, N.A.] КОНСТАНТИНОВA Н.A. 2001. Аннотированный список печеночников (Hepaticae). - [Annotated list of liverworts (Hepaticae)] В кн.: Мохообразные $и$ сосудистые растения территории Полярно-альпийского ботанического сада (Хибинские горы, Кольский полуостров) (ред. Константинова H.A.) [In: Konstantinova, N.A. (ed.) Mokhoobraznye i sosudistye rastenya territorii Polyarno-alpijskogo botanicheskogo sada (Khibinskie gory, Kol'skij poluostrov)] КНЦ РАH, Anamumb [Apatity, KSC RAS]: 15-29.

KONSTANTINOVA, N.A. 2001. Eremonotus myriocarpus (Carr.) Lindb. \& Kaal. - an addition to the hepatic flora of Russia. - Arctoa 10: 115-120.

KONSTANTINOVA, N.A. 2001. Hepatics in the third edition of Red Data Book of Murmansk Province. - In: Abstracts of 4-th European Conference of the Conservation on Bryophytes. Pruhonice: 19.

KONSTANTINOVA, N.A. 2001. Hepatics in Strict Nature Reserves of European part of Russia. - Novitates botanicae Universitatis Carolinae 15: 77-93.

[KONSTANTINOVA, N.A.] КОНСТАНТИНОВА Н.А. 2001. Введение. - [Introduction] В кн.: Мохообразные и сосудистые растения территории Полярно-альпийского ботанического сада (Хибинские горы, Кольский полуостров) (ред. Константинова H.A.) [In: Konstantinova, N.A. (ed.) Mokhoobraznye i sosudistye rastenya territorii Polyarno-alpijskogo botanicheskogo sada (Khibinskie gory, Kol'skij poluostrov)] КНЦ РAH, Anamumbl [Apatity, KSC RAS]: 5-7.

[KONSTANTINOVA, N.A.] КОНСТАНТИНОВА Н.A. 2001. Видовое разнообразие и таксономические спектры некоторых локальных флор печеночников Мурманской области. - [Species diversity and taxonomical spectrum of some local liverwort floras of Murmansk region] $В \kappa н$.: Проблемы сохранения биоразнообразия в наземных $и$ морских экосистемах севера. Тез. докл. международной конф. и выездной сессии Отделения общей биологии РАН, 27-31 августа 2001 г., Anamumbl [In: Problems of biodiversity preservation in ground and marine ecosystems in the north. Abstracts of International conference and guest session of the department of the general biology of the Russian Academy of Sciences, 26-31 August, Apatity] Anamumb [Apatity]: 20 . 
KONSTANTINOVA, N.A. 2001. State of knowledge on Bryophytes of Strict Nature Reserves (Zapovedniki) of European part of Russia. - In: Abstracts of 4-th European Conference of the Conservation on Bryophytes. Pruhonice: 10.

[KONSTANTINOVA, N.A. \& E.YU. KUZMINA] KOHCTAHТИНОВА Н.А., Е.Ю. КУЗЬМИНА. 2001. К флоре печеночников Корякии (Северо-Восток России). - [On the hepatic flora of Koryakiya (North East of Russia)] Arctoa 10: 103-114.

[KOSTINA, V.A., O.A. BELKINA \& N.A. KONSTANTINOVA] КОСТИНА В.А., О.А. БЕЛКИНА, Н.А. КОНСТАНТИНОВА. 2001. Краткий очерк природных условий. [Phytogeographic survey] В кн.: Мохообразные и сосудистыле растения территории Полярно-альпийского ботанического сада (Хибинские горы, Кольский полуостров) (ред. Константинова H.A.) [In: Konstantinova, N.A. (ed.) Bryophytes and vascular plants of the territory of Polar Alpine Botanical Garden (Khibiny Mountains, Kola Peninsula)] Anamumbl, изд-во КНЦ РАН [Apatity, Kola Sci. Centre of RAS]: $8-15$.

IGNATOV, M.S., E.A. IGNATOVA, T.V. AKATOVA \& N.A. KONSTANTINOVA. 2002. Bryophytes of the Khosta' Taxus and Buxus Forest (Western Caucasus, Russia). - Arctoa 11: $205-214$.

[KONSTANTINOVA, N.A.] КОНСТАНТИНОВА Н.A. 2002. Вклад Р.Н.Шлякова в развитие российской бриологии. [The contribution of R.N. Schljakov into the development of Russian bryology] В кн.: Проблемы бриологии на рубеже веков. Материаль международного совещания, посвященного 90-летию со дня рождения Романа Николаевича Шлякова (20.06.1912) и Ивана Ивановича Абрамова (14.07.1912), Санкт-Петербург, 4-6 ноября 2002 г. [In: Problems of bryology at the boundary of centries. Proceedings of the international conference devoted to 90-th anniversary of R.N. Schljakov (20.06.1912) and I.I. Abramov (14.07.1912), Sankt-Petersburg, November 4-6, 2002] CПб. [St.-Petersburg]: 3-7.

[KONSTANTINOVA, N.A.] КОНСТАНТИНОВА Н.A. 2002. Редкие и интересные виды печеночников (Hepaticae) в заповеднике Кузнецкий Алатау. - [Rare and interesting liverworts (Hepaticae) in the Reserve Kuznetskij Alatau] Вестник Томского государственного университета. Приложение 2, сентябр 2002 [Vestnik Tomskogo gosudarstvennogo universiteta, Suppl. 2, sept. 2002]: 28-31.

[KONSTANTINOVA, N.A.] КОНСТАНТИНОВА Н.A. 2002. Род Tetralophozia (R.M. Schust.) Schljakov (Lophoziaceae, Hepaticae) в России. - [The genus Tetralophozia (R.M. Schust.) Schljakov (Lophoziaceae, Hepaticae) in Russia] Arctoa 11: 45-52.

[KONSTANTINOVA, N.A. \& O.V. LAVRINENKO] KOHСТАНТИНОВА Н.А., О.В. ЛАВРИНЕНКО. 2002. К флоре Нераticae Ненецкого автономного округа (северо-восток европейской части России). - [On flora of Hepaticae of the Nenets Autonomous Area (Arkhangelsk Region, north-eastern European Russia] Ботанический журнал [Botanicheskij Zhurnal] 87(9): 43-49.

[KONSTANTINOVA, N.A. \& A.N. SAVCHENKO] KOHСТАНТИНОВА Н.А., А.Н.САВЧЕНКО. 2002. Проблема инвентаризации гербарных коллекций и ее решение в Полярно-Альпийском Ботаническом Саду КНЦ РАН
(KPABG). - [Problem of the inventory of herbarium collections and the approach to its solution in the Polar-Alpine Botanic Garden KSC RAS (KPABG)] В кн.: Проблемь бриологии на рубеже веков. Материалы международного совещания, посвященного 90-летию со дня рождения Романа Николаевича Шлякова (20.06.1912) и Ивана Ивановича Абрамова (14.07.1912), Санкт-Петербург, 46 ноября 2002 г. [In: Problems of bryology at the boundary of centries. Proceedings of the international conference devoted to 90-th anniversary of R.N. Schljakov (20.06.1912) and I.I. Abramov (14.07.1912), Saint-Petersburg, November 4-6, 2002] СПб. [St.-Petersburg]: 32-33.

STECH, M., N.A. KONSTANTINOVA \& W. FREY. 2002. Molecular divergence between Treubia Goebel and Apotreubia S.Hatt. \& Mizut., the two genera of the archaic liverwort class Treubiopsida (Hepaticophytina). - Nova Hedwigia 75(1-2): 91-100

SURAGINA, S.A., N.A. KONSTANTINOVA \& M.S. IGNATOV. 2002. Hepatics and Anthocerotae of the Volgograd Province. - Arctoa 11: 175-177.

BAKALIN, V.A. \& N.A. KONSTANTINOVA. 2003. Hepaticae Rossica Exsiccata. - Kirovsk, MUP "Polygraf", 19 pp.

[DULIN, M.V., N.A. KONSTANTINOVA \& V.A. BAKALIN] ДУЛИН М.В., Н.А. КОНСТАНТИНОВА, В.А. БАКАЛИН. 2003. К флоре печеночников Республики Коми. [On the liverwort flora of the Komi Republic] Ботанический журнал [Botanicheskij Zhurnal] 88(3): 45-52.

[KONSTANTINOVA, N.A.] КОНСТАНТИНОВА Н.А. 2003. Дополнение к флоре печеночников Хибин (Мурманская область). - [Addition to liverworts flora of the Khibiny Mts.] В кн.: Растительность и растительные ресурсы Европейского Севера России. Мат. Х Перфильевских чтений, посвященных 120-летию со дня рождения И.А. Перфильева (1882-1942). Архангельск, 25-27 марта 2002 г. [In. Rastitel 'nost' $i$ rastitel 'nye resursy Evropejskogo Severa Rossii. Materialy X Perfil'evskikh chtenij, posvyaschennykh 120-letiyu so dnya rozhdeniya I.A. Perfil'eva (1882-1942). Arkhangel'sk, 25-27 March 2002] Архангельск [Arkhangel'sk]: 45-47.

[KONSTANTINOVA, N.A] КОНСТАНТИНОВА Н.А. 2003. О фитогеографии печеночников архипелага Шпицберген. - [About phytogeography of liverworts of Spitzbergen archipelago] В кн.: Комплексные исследования природы Шпицбергена (Матер. конф.), Anaтumb [In: Kompleksnye issledovaniya prirody Spitzbergena, materialy conferentsii, Apatity]: 163-165.

[KONSTANTINOVA, N.A.] КОНСТАНТИНОВА Н.А. 2003. Печеночники южной Сибири: история изучения, характеристика флоры, направление дальнейших работ. - [Liverworts of South Siberia: history of study, characteristic of flora, direction of the further works] В кн.: Ботанические исследования в Азиатской России. Мат. ХІ съезда Русского ботанического общества (18-22 августа 2003 г., Новосибирск-Барнаул). Том.1 [Botanicheskie issledovaniya $v$ Aziatskoj Rossii. Mat. XI s'ezda Russkogo Botanicheskogo obshchestva (18-22 August 2003), Novosibirsk-Barnaul] Барнаул [Barnaul]: 207-209.

KONSTANTINOVA, N.A., V.A. BAKALIN, A.D. POTEMKIN \& M.S. IGNATOV. 2003. Hepatic flora of the Upper Bureya River (Russian Far East). - Arctoa 11: 393-398. 
[KONSTANTINOVA, N.A., O.A. BELKINA \& A.Yu. LIKHACHEV] КОНСТАНТИНОВА Н.А., О.А. БЕЛКИНА, А.Ю. ЛИХАЧЕВ. 2003. Мохообразные. - [Bryophytes] В кн.: Красная Книга Мурманской области (ред. Константинова Н.А., A.С.Корякин, О.А.Макарова) [In: Konstantinova, N.A., A.S. Koryakin \& O.A. Makarova (eds.) Red Data Book of the Murmansk Province] Мурманск, Мурманское книжное изд-во [Murmansk, Murmanskoe Knizhnoe Izdatelstvo]: 115-150.

[KONSTANTINOVA, N.A. \& N.E. KOROLEVA] KOHCTAHТИНОВА Н.А., Н.Е. КОРОЛЕВА. 2003. Необычные формы печеночников с архипелага Шпицберген. - [On some dwarf forms of Hepatics new for Spitzbergen archipelago] Тезисы 3 международной конференции "Комплексные исследования природы Шпицбергена”, Апатиты [Коmpleksnye issledovaniya prirody Spitzbergena. Proc. 3 Int. Conf. Apatity]: 156-161.

[KONSTANTINOVA, N.A., E.D. LAPSHINA \& E.Ya. MULDIYAROV] КОНСТАНТИНОВА Н.А., Е.Д. ЛАПШИНА, Е.Я. МУЛЬДИЯРОВ. 2003. К флоре печеночников (Неpaticae) заповедника Кузнецкий Алатау (Южная Сибирь). - [On the Hepatic flora of Strict Nature Reserve "Kuznetskij Alatau" (South Siberia)] Arctoa 12: 151-167.

[YATSENTYUK, S.P., N.A. KONSTANTINOVA, M.S. IGNATOV, J. HYVONEN \& A.V. TROITSKY] ЯЦЕНТЮК С.П., Н.А. КОНСТАНТИНОВА, М.С. ИГНАТОВ, Я. ХЮВОНЕН, А.В. ТРОИЦКИЙ. 2003. Изучение молекулярной филогении Jungermanniales путем анализа нуклеотидных последовательностей интрона гена $\operatorname{trnL}$ хлоропластной ДНК. - [Molecular phylogenetic study of Jungermanniales by the analysis of chloroplast trnL intron sequences] Тезисы докл. ХІ международного совещания по филогении pастений. М., МГУ и др. [Tezisy XI soveshchaniya po filogenii rastenij. Moscow, MSU]: 117-118.

[ANDREJEVA, V.N., O.A. BELKINA, V.A KOSTINA, N.A. KONSTANTINOVA \& G.P. URBANAVICHYUS] АНДРЕЕВА В.Н., О.А. БЕЛКИНА, В.А. КОСТИНА, Н.А. КОНСТАНТИНОВА, Г.П. УРБАНАВИЧЮС. 2004. Уникальный памятник природы в Хибинских горах (Мурманская область). - [Unique Natural Monument in the Khibiny Mts. (Murmansk Region)] В кн.: Природное наследие России: изучение, мониторинг, охрана. Материаль международной конферениии [In: Prirodnoe nasledie Rossii: izuchenie, monitoring, okhrana. Materialy mezhdunarodnoj konferentsii] Тольятти [Tol 'yatti]: 8-11.

BAKALIN, V.A. \& N.A. KONSTANTINOVA. 2004. Hepaticae Rossicae Exsiccatae. Fasc. II. (№№ 26-50). - Apatity, Apatit-Media: 14 pp.

KONSTANTINOVA, N.A. 2004. M.J.Wigginton (ed.) 2004. E.W. Jones's Liverwort and Hornwort flora of West Africa. Scripta Botanica Belgica, vol. 30, 443 p. -Arctoa 13: 210 (a review).

KONSTANTINOVA, N.A. 2004. Iwatsukia jishibae (Steph.) Kitagawa (Cephaloziaceae, Hepaticae) in Russia. - Arctoa 13: 203-209.

[KONSTANTINOVA, N.A.] КОНСТАНТИНОВА Н.А. 2004 Печеночники и антоцеротовые. - [Anthocerotae and Hepaticae] В кн.: Современное состояние биологического разнообразия на заповедных территориях России. Bып. 3. Лишайники и мохообразные (ред. Афонина О.М., Н.С. Голубкова) [In: Afonina, O.M. \& N.S. Golubkova (eds.) The present-day state of biological diversity within protected areas. Issue 3. Lichens and bryophytes. M., МСОП [Moscow, IUCN]: 236-273.

[KONSTANTINOVA, N.A.] КОНСТАНТИНОВА Н.А. 2004. Печеночники Керженского заповедника (Нижегородская область, Европейская часть России). - [Hepatics of the Kerzhenskiy State Reserve (Nizhniy Novgorod Province, European Russia)] Arctoa 13: 89-99.

[KONSTANTINOVA, N.A.] КОНСТАНТИНОВА Н.А. 2004. Печеночники Красной книги мохообразных Европы в заповедниках Европейской части России. - [Hepatics of Red Data List of Europe in reserves of European Russia] $B$ кн.: Принципы и способы сохранения биоразнообразия. Сб. мат. Всероссийской науч. конф., 18-24 сентября 2004 г., Йошкар-Ола [In: Principy $i$ sposoby sohraneniya bioraznoobraziya. Sb. Mat. Vserossijskoj nauch. konf., 1824 September 2004, Joshkar-Ola]: 93-94.

[KONSTANTINOVA, N.A., V.A. BAKALIN \& A.D. POTEMKIN] КОНСТАНТИНОВА Н.А., В.А. БАКАЛИН, А.Д. ПОТЕМКИН. 2004. Cephalozia pachycaulis (Hepaticae, Cephaloziaceae) - малоизвестный вид для флоры России. - [Cephalozia pachycaulis (Hepaticae, Cephaloziaceae), a little-known species in Russia] Ботанический журнал [Воtanicheskij Zhurnal] 89(12): 1890-1897.

[KONSTANTINOVA, N.A., V.A. ANDREEVA, O.A. BELKINA, V.A. KOSTINA, A.Yu. LIKHACHEV, I.N. URBANAVICHENE \& G.P. URBANAVICHYUS] КОНСТАНТИНОВA Н.А., В.А. АНДРЕЕВА, О.А. БЕЛКИНА, В.А. КОСТИНА, А.Ю. ЛИХАЧЕВ, И.Н.УРБАНАВИЧЕНЕ, Г.П. УРБАНАВИЧЮС. 2004. Флора ООПТ Мурманской области. - [Flora of protected areas of Murmansk Province] В кн.: Принципы и способы сохранения биоразнообразия. Сб. мат. Всероссийской науч. конф., 18-24 сентября 2004 г., Йошкар-Ола [In: Printsipy $i$ sposoby sohraneniya bioraznoobraziya. Sbornik Materialov Vserossijskoj nauchnoj konferentsii, 18-24 September 2004, Joshkar-Ola]: 94-96.

[KONSTANTINOVA, N.A. \& S.G. KAZANOVSKIY] KOHСТАНТИНОВА Н.А., С.Г. КАЗАНОВСКИЙ. 2004. Печеночники Байкальского заповедника. - [Mosses of the Baikalskij Reserve] В кн: Современное состояние биологического разнообразия на заповедных территориях России. Вып. 3. Лишайники и мохообразные (ред. Афонина O.M., H.C. Голубкова) [In: Afonina, O.M. \& N.S. Golubkova (eds.) The present-day state of biological diversity within protected areas. Issue 3. Lichens and bryophytes. M., МСОП [Moscow, IUCN]: 236-273.

[KONSTANTINOVA, N.A., V.A. KOSTINA \& A.N. SAVCHENKO] КОНСТАНТИНОВА Н.А., В.А. КОСТИНА, А.Н. САВЧЕНКО. 2004. Красная книга Мурманской области как основа мониторинга и охраны редких и исчезающих растений и лишайников региона. - [Red Data Book of the Murmansk Region as a basis of monitoring and protection of rare and vulnerable species of plants and lichens in the region] В кн.: Экологические проблемы северных регионов и пути их решения. Часть 2. Материаль международной конференции (Anатиты, 31 августа 3 сентября 2004 г.) [In: Ekologicheskie problemy severnykh regionov i puti ikh resheniya. Chast' 2 . Materialy mezdunarodnoj konferentsii (Apatity, 31August - 3 September 2004)] Anamumbl [Apatity]: 61-63. 
[KONSTANTINOVA, N.A. \& T.I. VARLYGINA] KOHCTAHТИНОВА Н.А., Т.И. ВАРЛЫГИНА. 2004. Печеночники Большого Арктического заповедника. - [Mosses of the Great Arctic State Nature Reserve] В кн: Современное состояние биологического разнообразия на заповедных территориях России. Вып. 3. Лишайники и мохообразные (ред. Афонина О.М., Н.С. Голубкова) [In: Afonina, O.M. \& N.S. Golubkova (eds.) The present-day state of biological diversity within protected areas. Issue 3. Lichens and bryophytes. M., MCOП [Moscow, IUCN]: 236-273.

YATSENTYUK, S.P., N.A. KONSTANTINOVA, M.S. IGNATOV, J. HYVONEN \& A.V. TROITSKY. 2004. On phylogeny of Lophoziaceae and related families (Hepaticae, Jungermanniales) based on trnL-trnF intron-spacer sequences of chloroplast DNA. - Molecular systematics of Bryophytes. Monographs in Systematic Botany from the Missouri Botanical Garden 98: 141-149.

[BELKINA, O.A., N.A. KONSTANTINOVA, N.E. KOROLEVA, V.A. KOSTINA \& I.N. URBANAVICHENE] БЕЛКИНА О.А., Н.А. КОНСТАНТИНОВА, Н.Е. КОРОЛЕВА, В.А. КОСТИНА, И.Н. УРБАНАВИЧЕНЕ. 2005. Ботанические экскурсии по Хибинским и Ловозерским горам. - [Botanical excursions to Khibines and Lovozersky Mountains] Kировск [Kirovsk], 120 pp.

IGNATOV, M.S., E.A. IGNATOVA \& N.A. KONSTANTINOVA. 2005. Bryophyte flora of the Volzhsko-Kamskiy Nature Reserve (Tatarstan, European Russia). - Arctoa 14: 49-66.

IGNATOVA, E.A., M.S. IGNATOV, A.P. SEREGIN, T.V. AKATOVA \& N.A. KONSTANTINOVA. 2005. Bryophyte flora of the projected Utrish Nature Reserve (North-West Caucasus, Russia). - Arctoa 14: 39-48.

[KONSTANTINOVA, N.A] КОНСТАНТИНОВА Н.А. 2005. Дополнение к флоре печеночников Хибин (Мурманская область). - [On the hepatics flora of Khibiny Mountains (Murmansk Region)] В кн.: Актуальные проблемы сохранения биоразнообразия растительного и животного мира Северной Фенноскандии и сопредельных территорий (ред. В.Н. Переверзев) [In: Pereverzev, V.N. (ed.) Aktual'nyye problemy sokhraneniya bioraznoobraziya rastitel'nogo i zhivotnogo mira Severnoj Fennoskandii i sopredel'nykh territorij] Москва, КМК [Moscow, KMK]: 14-18.

[KONSTANTINOVA, N.A.] КОНСТАНТИНОВА Н.A. 2005. Изучение разнообразия печеночников в заповедниках России. - [Diversity of hepatics in Strict Nature Reserves of Russia] В кн.: Актуальные проблемы бриологии, Tp. междунар. совещания, посв. 90-летию со дня рожд. А.Л. Абрамовой. Санкт-Петербург, 22-25 ноября 2005 [Р Рос. Int. Conf. "Actual Problems of Bryology" devoted to 90th Anniversary of A.L. Abramova. St. Petersburg, 22-25 November 2005] СПб. [St. Petersburg]: 104-112.

[KONSTANTINOVA, N.A., O.A. BELKINA, N.E. KOROLEVA \& V.A. KOSTINA] КОНСТАНТИНОВА Н.A., О.A. БЕЛКИНА, Н.Е. КОРОЛЕВА, В.А. КОСТИНА. 2005. Проектируемый национальный парк «Хибины» как важнейший центр разнообразия растений и растительности в Мурманской области. - [Proposed Nature Park «Khibiny» (Murmansk Provice) - one of the most important sites of plant diversity in European North of Russia] В кн.: Актуальные проблемы сохранения биоразнообразия растительного и животного мира Северной Фенноскандии и сопредельных территорий (ред. В.Н. Переверзев) [In: Pereverzev, V.N. (ed.)
Aktual 'nyye problemy sokhraneniya bioraznoobraziya rastitel'nogo i zhivotnogo mira Severnoj Fennoskandii i sopredel'nykh territorij] Москва, KMK [Moscow, KMK]: 293-296.

[KONSTANTINOVA, N.A. \& V.A. KOSTINA] KOНCTAHТИНОВА Н.А., В.А. КОСТИНА. 2005. Изучение флоры Мурманской области (1980-2005). - [Investigating of the flora of the Murmansk Region in 1980-2005)] В кн.: Формирование основ современной стратегии природопользования в Евро-Арктическом регионе [In: Formirovanie osnov sovremennoj strategii prirodopol'zovaniya $v$ EvroArkticheskom regione] Anamumbl [Apatity]: 79-86.

KOROLEVA, N.E., N.A. KONSTANTINOVA, I.N. URBANAVICHENE, G.P. URBANAVICHYUS, N.YU. SHMAKOVA \& D.A. DAVYDOV] Н.E. КОРОЛЕВA, Н.A. КОНСТАНТИНОВА, И.Н. УРБАНАВИЧЕНЕ, Г.П. УРБАНАВИЧЮС, Н.Ю. ШМАКОВА, Д.А. ДАВЫДОВ. 2005. Комплексные исследования Полярно-альпийского ботанического сада-института на архипелаге Шпицберген. - [The complex investigation of the Svalbard nature conducted by Polar-Alpine Botanical Garden-Institute] $B \kappa \mu$.: Комплексные исследования природы Шпицбергена (Матер. конф.). Anатиты [In: Kompleksnye issledovaniya prirody Spitzbergena. Proc. 5 Int. Conf., Apatity]: 396-404.

[KOSTINA, V.A., G.P. URBANAVICHUS, O.A. BELKINA, N.A. KONSTANTINOVA \& I.N. URBANAVICHENE] КОСТИНА В.А., Г.П. УРБАНАВИЧЮС, О.А. БЕЛКИНА, Н.А. КОНСТАНТИНОВА, И.Н. УРБАНАВИЧЕНЕ. 2005. Материалы по разнообразию растений и лишайников проектируемых охраняемых территорий на Мурманском побережье Белого моря. - [Materials on diversity of plants and lichens in planned protected areas on the Murman coast of the White Sea] В кн.: Труды Беломорской биостаниии биологического факультета МГУ. [In: Trudy Belomorskoj biostantsii biologicheskogo facul teta MGU] 10: 87-91.

[VILNET, A.A., I.A. MILYUTINA, A.V. TROITSKY \& N.A. KONSTANTINOVA] ВИЛЬНЕТ А.А., И.А. МИЛЮТИНА, А.В. ТРОИЦКИЙ, Н.А. КОНСТАНТИНОВА. 2005. К филогении и систематике рода Lophozia (Dumort.) Dumort. s. str. на основании анализа последовательностей $t r n \mathrm{~L}-t r n \mathrm{~F}$ хлоропластной ДНК и ITS 1-2 ядерной ДНК. [In phylogeny and systematics of genus Lophozia (Dumort.) Dumort. s. str. based on $\operatorname{trn} \mathrm{L}-\operatorname{trn} \mathrm{F}$ sequences of chloroplast DNA and ITS 1-2 sequences of nuclear DNA] В кн.: Актуальные проблемы бриологии, Тр. междунар. совещчания, посв. 90-летию со дня рожд. А.Л. Абрамовой. СанктПетербург, 22-25 ноября 2005 [In: Proc. Int. Conf. "Actual Problems of Bryology" devoted to 90th Anniversary of A.L. Abramova. St. Petersburg, 22-25 November 2005] CПб. [St.-Petersburg]: 37-43.

[AFONINA, O.M. \& N.A. KONSTANTINOVA] АФОНИНА O.М., Н.А. КОНСТАНТИНОВА. 2006. Мохообразные. [Bryophytes] В кн.: Красная книга Ненеикого автономного округа. Официальное издание (ред. Матвеева Н.B.) [In: Matveeva, N.V. (ed.) Red Data Book of Nenetsky Autonomous District. Official edition] Нарьян-Map [Naryan-Mar]: 108-125.

[KONSTANTINOVA, N.A., V.A. BAKALIN \& A.N. SAVCHЕNКО] КОНСТАНТИНОВА Н.А., В.А. БАКАЛИН, А.Н. САВЧЕНКО. 2006. Эксикаты печеночников России. Вып. 3. - [Exsiccates of liverworts of Russia. Fasc. 3] Anamuты [Apatity]: 20 pp. 
[KONSTANTINOVA, N.A. \& A.G. BEZGODOV] KOHCTAHТИНОВА Н.А., А.Г. БЕЗГОДОВ. 2005. Печеночники Вишерского заповедника (Пермская область, Северный Урал). - [Hераtics of Vishera State Nature Reserve (Perm Province, Northern Ural Mountains)] Arctoa 14: 163-176.

[KONSTANTINOVA, N.A. \& E.A. BOROVICHEV] KOHСТАНТИНОВА Н.А., Е.А. БОРОВИЧЕВ. 2006. К флоре печеночников (Нераticae) Мурманской области. - [Тo the liverwort flora of Murmansk (Hepaticae) Province] Ботанический журнал [Botanicheskij Zhurnal] 91(2): 322-328.

[KONSTANTINOVA, N.A. \& A.N. SAVCHENKO] KOHСТАНТИНОВА Н.А., А.Н. САВЧЕНКО. 2006. О находках редких для Шпицбергена печеночников на западном побережье Бокк-фьорда. - [About records of liverworts rare in Svalbard on western coast of Bokk-fjord] В кн.: Комплексные исследования природы Шпицбергена. Bып. 6. Апатиmbl [In: Kompleksnye issledovaniya prirody Shpitsbergena. Vyp. 6. Apatity]: 330-336.

[KONSTANTINOVA, N.A., I.N. URBANAVICHENE \& G.P. URBANAVICHUS] КОНСТАНТИНОВА, Н.А., И.Н. УРБАНАВИЧЕНЕ, Г.П. УРБАНАВИЧЮС. 2006. Памяти Анны Владимировны Домбровской (1926-2004). - [In memoriam: Anna Vladimirovna Dombrovskaya (1926-2004)] Ботанический журнал [Botanicheskij Zhurnal] 91(1): 160-168.

[ONIPCHENKO, V.G., A.D. SALPAGAROV, M.S. IGNATOV, E.A. IGNATOVA \& N.A. KONSTANTINOVA] ОНИПЧЕНКО В.Г., А.Д. САЛПАГАРОВ, М.С. ИГНАТОВ, Е.А. ИГНАТОВА, Н.А. КОНСТАНТИНОВА. 2006. Ботанические исследования и изучение высокогорных экосистем в Тебердинском заповеднике. - [Botanical investigation and study of high mountain ecosystems in Teberdinskij Reserve] Труды Тебердинского гос. биосф. заповедника [Trudy Teberdinskogo gosudarstvennogo biosfernogo zapovednika] 42: 190-209.

VILNET, A.A., N.A. KONSTANTINOVA \& A.V. TROITSKY. 2006. The molecular divergence between some closely allied taxa of genus Scapania (Dumort.) Dumort. $-B \kappa н$.: Устойчивость экосистем и проблема сохранения биоразнообразия на Севере. Материаль международной конференции [In: Sustainable of ecosystems and problems of preservation of biological diversity in the North. Proc. int.conf.] Кировск [Kirovsk]: 49-53.

[KONSTANTINOVA, N.A.] КОНСТАНТИНОВА Н.А. 2007. Новый для России род Anastrepta (Lindb.) Schiffn. (Lophoziaceae, Hepaticae). - [Anastrepta (Lindb.) Schiffn. (Lophoziaceae, Hepaticae), a new genus for Russia] Ботанический журнал [Botanicheskij Zhurnal] 92(12): 1934-1938.

[KONSTANTINOVA, N.A] КОНСТАНТИНОВА Н.А. 2007. Печеночники. - [Liverworts] В кн. Красная книга Краснодарского края (Растения и грибы). Издание второе (ред. Литвинская C.A.) [In: Litvinskaya S.A. (ed.) Red Data Book of Krasnodar Territory (Plants and Fungi). Izdanie vtoroe] Краснодар, “Дизайн бюро №1" [Krasnodar, "Dizain byuro №1"]: 450-456.

KONSTANTINOVA, N.A. 2007. On worldwide disjunctive distribution of rare hepatics in Siberia, Russia. - In: Abstracts: World conference of bryology: Bryology in Asia in the new Millennium. Kuala Lumpur: 59.

[KOSTINA, V.A., O.A. BELKINA \& N.A. KONSTANTINOVA] КОСТИНА В.А., О.А. БЕЛКИНА, Н.А. КОНСТАН-
ТИНОВА. 2007. Ключевые ботанические территории Мурманской области. - [Key botanical territories of Murmansk Province] В кн.: Проблемь региональной экологии в условиях устойчивого развития. Сб. матер. Всеросс. научно-практ. конф. (Киров, 27-29 ноября 2007 г.) в 2 частяx. Чacmb I [In: Problemy regional'noj ekologii v usloviyakh ustojchivogo razvitiya. Sbornik materialov Vserossijskoj nauchno-prakticheskoj konferentsii (Kirov, 27-29 November 2007) v 2 chastyakh. Chast' I] Киров, Изд-во ВятГУ [Kirov, Vyatsk. Gos. Univ.]: 46-49.

[KONSTANTINOVA, N.A. \& A.N. SAVCHENKO] KOHСТАНТИНОВА Н.А., А.Н. САВЧЕНКО. 2007. Новые и редкие на Шпицбергене печеночники в окрестностях Баренцбурга. - [New and rare hepatics for Svalbard in vicinities of Barentzburg] В кн.: Комплексные исследования nрироды Шпицбергена. Bыn.7. Anamumbl [In: Kompleksnye issledovaniya prirody Shpitsbergena. Vyp. 7. Apatity]: 265-278.

[KONSTANTINOVA, N.A., A.A. VILNET \& A.V TROITSKY] КОНСТАНТИНОВА Н.А., А.А. ВИЛЬНЕТ, А.В. ТРОИЦКИЙ. 2007. О филогении и систематике печеночников (Hepaticae) в свете молекулярных данных. - [Phylogeny and systematics of Hepatics as evidenced by molecular data] Тезисы конф. по систематике и морфологии растений, посвящ. 300-летию со дня рождения Карла Линнея. $16-$ 18 мая 2007 [Materialy konferentsii po morfologii i sistematike rastenij, posvyashchennoj 300-letiyu so dnya rozhdeniya Karla Linneya, Moscow, 16-19 May 2007. Москва, KMK [Moscow, KMK]: 68-70.

[VILNET, A.A. \& N.A. KONSTANTINOVA] ВИЛЬНЕT A.A., Н.А. КОНСТАНТИНОВА. 2007. О молекулярной филогении семейства Scapaniaceae Mig. (Hepaticae). - [Molecular phylogeny of Scapaniaceae Mig. (Hepaticae)] Тезисы конф. по систематике и морфологии растений, посвящ. 300-летию со дня рождения Карла Линнея. 16-18 мая 2007. Москва, КМК [Materialy konferentsii po morfologii i sistematike rastenij, posvyashchennoj 300-letiyu so dnya rozhdeniya Karla Linneya, Moscow, 16-19 May 2007. Moscow, KMK]: 53-55.

[VILNET, A.A., N.A. KONSTANTINOVA \& A.V TROITSKY] ВИЛЬНЕТ А.А., Н.А. КОНСТАНТИНОВА, А.В. ТРОИЦКИЙ. 2007. К молекулярной филогении семейства Gymnomitriaceae H. Klinggr. (Hepaticae). - [On the molecular phylogeny of Gymnomitriaceae H. Klinggr. (Hepaticae)] В кн.: Материаль международной конференции «Вычислительная филогенетика и геносистематика». МГУ, Москва [In: Materialy mezhdunarodnoj konferentsii "Vychislitel'naya filogenetika i genosistematika". MSU, Moscow]: 24-26.

[VILNET, A.A., I.A. MILYUTINA, N.A. KONSTANTINOVA, M.S. IGNATOV \& A.V. TROITSKY] ВИЛЬНЕТ А.A., И.А. МИЛЮТИНА, Н.А. КОНСТАНТИНОВА, М.С. ИГНАТОВ, А.В. ТРОИЦКИЙ. 2007. Филогения рода Lophozia (Dumort.) Dumort. s.str. на основе анализа ядерных и хлоропластных последовательностей, ITS1-2 и trnL-F. [Phylogeny of the genus Lophozia (Dumort.) Dumort. s.str. based on nrITS1-2 and cptrnL-F] Генетика [Russian Journal of Genetics] 43(11): 1556-1564.

[AFONINA, O.M. \& N.A. KONSTANTINOVA] АФОНИНА О.М., Н.А. КОНСТАНТИНОВА. 2008. Мохообразные. [Bryophytes]. - В кн.: Красная книга Чукотского авто- 
номного округа. Том 2. Растения (ред. Черешнев И.A.) [In: Chereschnev, I.A. (ed.) Red Data Book of the Chukchi Autonomous District] Магадан, Издательский дом "Дикий Север" [Magadan, Publishing house "Dikij Sever']: 125-165.

AFONINA, O.M., V.A. BAKALIN, L.V. BARDUNOV, I.V. CZERNYADJEVA, M.V. DULIN, V.E. FEDOSOV, M.S. IGNATOV, E.A. IGNATOVA, E.I. IVANOVA, S.G. KAZANOVSKY, Z.Kh. KHARZINOV, N.A. KONSTANTINOVA, A.I. MAKSIMOV, M.G. NAPREENKO, A.D. POTEMKIN, E.V. SOFRONOVA \& G.V. ZHELEZNOVA] АФОНИНА O.M., В.А. БАКАЛИН, Л.В. БАРДУНОВ, И.В. ЧЕРНЯДЬЕВА, М.В. ДУЛИН, В.Э. ФЕДОСОВ, М.С. ИГНАТОВ, Е.А. ИГНАТОВА, Е.И. ИВАНОВА, С.Г. КАЗАНОВСКИЙ, Н.А. КОНСТАНТИНОВА, З.Х. ХАРЗИНОВ, А.И МАКСИМОВ, М.Г. НАПРЕЕНКО, А.Д. ПОТЕМКИН, Е.В. СОФРОНОВА, Г.В. ЖЕЛЕЗНОВА. 2008. Мохообразные. - [Bryophytes] $B$ кн.: Красная книга Российской Федераџии (растения и грибы) (ред. Трутнев Ю.П. и др.) [In: Trutnev, Yu.P. et al. (eds.) Red Data Book of Russian Federation (plants and fungi] Москва, КMК [Moscow, KMK]: 606-660.

[IGNATOVA, E.A., M.S. IGNATOV, N.A. KONSTANTINOVA, V.I. ZOLOTOV \& V.G. ONIPCHENKO] ИГНАТOВA Е.А., М.С. ИГНАТОВ, Н.А. КОНСТАНТИНОВА, В.И. ЗОЛОТОВ, В.Г. ОНИПЧЕНКО. 2008. Флора мохообразных Тебердинского заповедника. - [Bryophytes of Teberdinskiy State Nature Reserve] Флора и фауна заповедников [Flora i fauna zapovednikov] 112: 1-86.

[KONSTANTINOVA, N.A.] КОНСТАНТИНОВА Н.А. 2008. Разнообразие печеночников Российской части Кавказа. [Liverwort diversity in Russian Caucasus] В кн.: Фундаментальные и прикладные проблемы ботаники в начале XXI века. Материаль Всероссийской конферениии (Петрозаводск, 22-27 сентября 2008 г.). Часть 2. Альгология, микология, лихенология, бриология [In: Fundamental'nye $i$ prikladnye problemy botaniki v nachale XXI veka. Materialy Vserossiyskoj konferentsii (Petrozavodsk, 22-27 September 2008). Chast' 2. Al'gologiya, Mikologiya, Likhenologiya, Briologiya] Петрозаводск [Petrozavodsk]: 306-309.

[KONSTANTINOVA, N.A., L.I. ABRAMOVA., V.A. BAKALIN., A.A. NOTOV \& V.R. FILIN] KOНСТАНTИНОВA Н.А., Л.И. АБРАМОВА, В.А. БАКАЛИН, А.А. НОТОВ, В.Р. ФИЛИН. 2008. Аннотированный список печеночных мхов полуострова Киндо, Великая Салма, Кандалакшский залив. - [Annotated list of liverworts from Kindo Peninsula, Velikaya Salma, Kandalaksha gulf] В кн.: Летопись природы Кандалакшского заповедника за 2007 г. [In: Letopis prirody Kandalakshskogo zapovednika za 2007 god] Кандалакша [Kandalaksha]: 53(1): 116-121.

[KONSTANTINOVA, N.A., L.I. ABRAMOVA., V.A. BAKALIN., A.A. NOTOV \& V.R. FILIN] КОНСТАНТИНОВA Н.А., Л.И. АБРАМОВА, В.А. БАКАЛИН, А.А. НОТОВ, В.Р. ФИЛИН. 2008. Отдел Marchantiophyta, Маршанциевидные. - [Marchantiophyta] В кн.: Каталог биоть Беломорской биологической станции МГУ (ред. Чесунов A.B., Н.М. Калякина, Е.Н. Бубнова) [In: Tchesunov, A.V., N.M. Kaliakina \& E.N. Bubnova (eds.). Katalog bioty Belomorskoj biologicheskoj stantsii MGU] Москва, КМК [Moscow, KMK]: 186-190.

KONSTANTINOVA, N., O. BELKINA \& A. MELEKHIN. 2008. Sammal- ja jäkälälajiston monimuotoisuus Murmanskin alueella. - In: Kauhanen H., T. Kuuluvainen, A.-L. Yli- sirniö \& E. Huhta (toim.) Pohjoiset havumetsät - tutkimustuloksia ekologiseen metsänhoitoon. Kolari: 43-50.

[KONSTANTINOVA, N.A., A.V. MELEKHIN \& A.N. SAVCНЕNКО] КОНСТАНТИНОВА Н.А., А.В. МЕЛЕХИН, А.Н. САВЧЕНКО. 2008. О создании ботанического памяТника природы в долине реки Цага. - [On creating of Botanical Sanctuary in valley of Zaga River] Вестник МГТУ [Vestnik Murmanskogo Gosudarstvennogo Tekhnicheskogo Universiteta] 11(3): 519-525.

KONSTANTINOVA, N.A. \& A.N. SAVCHENKO. 2008. Additions to the hepatic flora of Russian part of the Caucasus. - Journal of Bryology 30(4): 306-309.

KONSTANTINOVA, N.A. \& A.N. SAVCHENKO. 2008. Contributions to the hepatic flora of Svalbard. - Lindbergia 33: $13-22$.

KONSTANTINOVA, N.A. \& A.N. SAVCHENKO. 2008. Diversity and phytogeography of hepatics of Siberia (Russia). - In: Mohamed, H., B.B. Baki, A. Nasrulhag-Boyce \& P.K.Y. Lee (eds.). Bryology in the New Millennium. Kuala Lumpur: University of Malaya: 155-172.

[KONSTANTINOVA, N.A. \& A.N. SAVCHENKO] KOHСТАНТИНОВА Н.А., А.Н. САВЧЕНКО. 2008. К распространению редких на архипелаге Шпицберген печеночников в окрестностях пос. Пирамида. - [On the distibution of liverworts rare for the Svalbard Archipelago, around Piramida (Pyramiden) Settlement] В кн.: Природа шельфа и архипелагов Европейской Арктики. Вып. 8. Мат. междун. научной конф. (Мурманск, 9-11 ноября 2008 г.) [In: Priroda shel'fa i arkhipelagov Evropejskoj Arktiki. Vyp. 8. Materialy mezhdunarodnoj nauchnoj konferentsii (Murmansk, 9-11 November 2008)] M. [Moscow]: 33-37.

[KONSTANTINOVA, N.A. \& A.N. SAVCHENKO] KOHСТАНТИНОВА Н.А., А.Н. САВЧЕНКО. 2008. Печеночники. - [Liverworts] В кн.: Флора и растительность побережья залива Грен-Фьорд (архипелаг Шиицберген) (ред. Константинова Н.А., Н.Е. Королева) [In: Konstantinova, N.A. \& N.E. Koroleva (eds.) Flora i rastitel'nost' poberezhya zaliva Grøn-Fjord (arkhipelag Spitsbergen)] Anamumb [Apatity]: $54-80$.

KONSTANTINOVA, N.A., A.A. VILNET \& A.N. SAVCHENKO. 2008. On distribution and variability of hepatics in Svalbard. - In: Programme and Abstracts of 18th International Symposium "Biodiversity and Evolution Biology": 245.

VILNET, A.A., N.A. KONSTANTINOVA \& A.V. TROITSKY. 2008. Phylogeny and systematics of the genus Lophozia s. str. (Dumort.) Dumort. (Hepaticae) and related taxa from nuclear ITS1-2 and chloroplast trnL-F sequences. - Molecular Phylogenetics and Evolution 47: 403-418.

VILNET, A.A., N.A. KONSTANTINOVA \& A.V. TROITSKY. 2008. Phylogeny of suborder Jungermanniineae (Hepaticae) based on ITS1-2 nrDNA and trnL-F cpDNA sequences data. -In: Programme and Abstracts of $18^{\text {th }}$ International Symposium "Biodiversity and Evolution Biology". Göttingen: 339.

[VILNET, A.A., N.A. KONSTANTINOVA \& A.V. TROITSKY] ВИЛЬНЕТ А.А., Н.А. КОНСТАНТИНОВА, А.В. ТРОИЦКИЙ. 2008. Молекулярная филогения печеночников подпорядка Jungermanniineae на основе ITS1-2 ядерной ДНК и trnL-F хлоропластной ДНК. - [Molecular phylogeny of Jungermanniineae (Hepaticae) based on nuclear ITS12 and chloroplast trnL-F sequences] В кн.: Фундаменталь- 
ные и прикладные проблемы ботаники в начале ХХІ века. Материаль Всероссийской конференичии (Петрозаводск, 22-27 сентября 2008 г.). Часть 2. Альгология, микология, лихенология, бриология. [In: Fundamental'nye i prikladnye problemy botaniki v nachale XXI veka. Materialy Vserossiyskoj konferentsii (Petrozavodsk, 22-27 September 2008). Chast' 2. Al'gologiya, Mikologiya, Likhenologiya, Briologiya] Петрозаводск [Petrozavodsk]: 288-291.

[ZHIROV, D.V., V.I. POZHILENKO, V.A. KOSTINA, N.E. KOROLEVA, I.V. VDOVIN, O.A. BELKINA, N.A. KONSTANTINOVA, V.N. PETROV, D.A. DAVYDOV \& A.V. MELEKHIN] ЖИРОВ Д.В., В.И. ПОЖИЛЕНКО, В.А. КОСТИНА, Н.Е. КОРОЛЕВА, И.В. ВДОВИН, О.А. БЕЛКИНА, Н.А. КОНСТАНТИНОВА, В.Н. ПЕТРОВ, Д.А. ДАВЫДОВ, А.В. МЕЛЕХИН. 2008. Ловозерский район. - [Lovozero District] В кн.: Книга 2-я из серии "Памятники природы и достопримечательности Мурманской области" [In: Kniga 2-ya iz serii "Pamyatniki prirody i dostoprimechatel 'nosti Murmanskoj oblasti”'] Санкт-Петербург [Sankt-Peterburg], 144 pp.

[AKATOV, V.V., N.A. KONSTANTINOVA \& T.V. AKATOVA] АКАТОВ В.В., Н.А. КОНСТАНТИНОВА, Т.В. АКАТОВА. 2009. Проблемы сохранения редких видов в Кавказском заповеднике. Изоляция местообитаний. - [Problems of conservation of rare species in Caucasian Reserve. Isolation of habitats] В кн.: Труды КГПБЗ, Вып. 19: Особо охраняемые виды животных, растений и грибов в Кавказском заповеднике. [In: Trudy Kavkazskogo Gos. Prir. Biosf. Zap. Vyp. 19: Osobo okhranyaemye vidy zhivotnykh, rastenij i gribov v Kavkazskom zapovednike] Maйкоn [Maikop]: 205-206.

BOROVICHEV, E.A., N. KALINAUSKAITË \& N.A. KONSTANTINOVA. 2009. On the distribution of Conocephalum conicum and C. salebrosum (Marchantiophyta) in Russia. Arctoa 18: 115-120.

[BOROVICHEV, E.A. \& N.A. KONSTANTINOVA] БOPOВИЧЕВ Е.А., Н.А. КОНСТАНТИНОВА. 2009. Род Сопоcephalum Wigg. в Мурманской области. - [Genus Conocephallum Wigg. in Murmansk Region] В кн.: Биологическое разнообразие северных экосистем в условиях изменяющегося климата (Тезисы докладов международной научной конференции, Anатиты [In: Biological diversity of the northern ecosystems under changeable climate (Abstracts of International Science Conference, Apatity)]: 6-7.

[KONSTANTINOVA, N.A.] КОНСТАНТИНОВА Н.А. 2009. Виды животных, растений и грибов Кавказского заповедника, включенные или рекомендуемые для включения в Красные книги. Печеночники. - [Animal, plant and fungi species of the Caucasian Reserve included or recommended for Red Data Books. Liverworts] В кн.: Труды КГПБ3, Bылn. 19: Особо охраняемые виды животных, растений и грибов в Кавказском заповеднике [In: Trudy Kavkazskogo Gosudarstvennogo Prirodnogo Biosfernogo Zapovednika. Vyp. 19: Osobo okhranyaemye vidy zhivotnykh, rastenij i gribov v Kavkazskom zapovednike] Maйкon [Maikop]: 161-164.

[KONSTANTINOVA, N.A.] КОНСТАНТИНОВА Н.A. 2009. Задачи изучения разнообразия печеночников Мурманской области. - [Problems of the study of liverworts in Murmansk Province] В кн.: Сохранение биологического разнообразия наземных и морских экосистем в условиях высоких широт: Материалы научно-практической конференции
(МГПУ, Мурманск 13-15 апреля 2009 г.) [In: Sokhranenie biologicheskogo raznoobraziya nazemnykh i morskikh ecosystem $v$ usloviyakh vysokikh shirot. Materialy nauchnoprakticheskoj konferentsii (MGPU, Murmansk 13-15 April 2009] Мурманск [Murmansk]: 122-125.

[KONSTANTINOVA, N.A.] КОНСТАНТИНОВА Н.A. 2009. Флора и микобиота заповедника. Печеночники. - [Flora and biota of fungi of the Reserve. Liverworts] В кн.: Труды КГПБЗ, Bып. 19: Особо охраняемые виды животных, растений и грибов в Кавказском заповеднике [In: Trudy Kavkazskogo Gosudarstvennogo Prirodnogo Biosfernogo Zapovednika. Vyp. 19: Osobo okhranyaemye vidy zhivotnykh, rastenij i gribov $v$ Kavkazskom zapovednike] Maйкon [Maikop]: 31-32.

KONSTANTINOVA, N.A. \& O.M. AFONINA. 2009. New liverwort records from Agin-Buryat Autonomous District (South Siberia). - Arctoa 18: 275.

KONSTANTINOVA, N.A., T.V. AKATOVA \& A.N. SAVCHENKO. 2009. Hepatics of Caucasian State Nature Reserve (Western Caucasus, Russia). - Arctoa 18: 121-134.

KONSTANTINOVA, N.A., V.A. BAKALIN, E.N. ANDREJEVA, A.G. BEZGODOV, E.A. BOROVICHEV, M.V. DULIN \& Yu.S. MAMONTOV. 2009. Checklist of liverworts (Marchantiophyta) of Russia. - Arctoa 18: 1-63.

KONSTANTINOVA, N.A., V.A. BAKALIN, Yu.S. MAMONTOV \& A.N. SAVCHENKO. 2009. New liverwort records from Buryatiya (South Siberia) 1. - Arctoa 18: 270-273.

[KONSTANTINOVA, N.A., O.A. BELKINA, D.A. DAVYDOV \& V.A. KOSTINA] КОНСТАНТИНОВА Н.A., О.А. БЕЛКИНА, Д.А. ДАВЫДОВ, В.А. КОСТИНА. 2009. Анализ видового разнообразия растений, лишайников и цианопрокариот ООПТ Мурманской области. - [Biodiversity of plants, lichens and cyanoprocaryotes of protected areas of Murmansk Province] В кн.: Разнообразие растений, лишайников и цианопрокариот Мурманской области: итоги изучения и перспективы охраны (ред. Константинова H.A.) [In: Konstantinova, N.A. (ed.) Raznoobrazie rastenij, lishainikov i cianoprokariot Murmanskoj oblasti: itogi izucheniya i perspektivy ohrany] Санкт-Петербург [Sankt-Petersburg]: 100-105.

KONSTANTINOVA, N.A. \& A.G. BEZGODOV. 2009. New liverwort records from Ural. - Arctoa 18: 258.

[KONSTANTINOVA, N.A., G.A. BOGDANOV \& A.N. SAVCHENKO] КОНСТАНТИНОВА Н.А., Г.А. БОГДАНОВ, А.Н. САВЧЕНКО. 2009. Печеночники (Marchantiophyta) и антоцеротовые (Anthocerotophyta) заповедника "Большая Кокшага” (Республика Марий Эл, центр европейской части России). - [Liverworts (Marchantiophyta) and hornworts (Anthocerotophyta) of State Nature Reserve "Bol'shaya Kokshaga"] Новости систематики низших растений [Novosti sistematiki nizshikh rastenij] 42: 252-265.

[KONSTANTINOVA, N.A., E.A. BOROVICHEV \& A.N. SAVCHENKO] КОНСТАНТИНОВА Н.A., Е.A. БОРОВИЧЕВ, А.Н. САВЧЕНКО. 2009. Печеночники. [Liverworts] В кн.: Разнообразие растений, лишайников и цианопрокариот Мурманской области: итоги изучения и перспективы охраны. (ред. Константинова H.A.) [In: Konstantinova, N.A. (ed.) Raznoobrazie pastenij, lishainikov i cianoprokariot Murmanskoj oblasti: itogi izucheniya i perspektivy ohrany] Санкт-Петербург [SanktPetersburg]: 40-49. 
KONSTANTINOVA, N.A., M.S. IGNATOV, E.A. IGNATOVA \& Z.Kh. KHARSINOV. 2009. New liverwort records from Kabardino-Balkaria. - Arctoa 18: 263-267.

[KONSTANTINOVA, N.A., N.E. KOROLEVA \& A.N. SAVCHЕNКО] КОНСТАНТИНОВА Н.А., Н.Е. КОРОЛЕВА, А.Н. САВЧЕНКО. 2009. Глава 3. Исследование растительного покрова архипелага Шпицберген. - [Chapter 3. Study of the vegetation of Spitzbergen] В кн.: Наука на Шпицбергене: История российских исследований (ред. Калинников B.T.) [In: Kalinnikov, V.T. (ed.) Nauka na Shpitsbergene. Istoriya rossijskikh issledovanij] Санкт-Петербург, Гамас [St.-Petersburg, Gamas]: 190-205.

KONSTANTINOVA, N.A. \& Yu.S. MAMONTOV. 2009. New liverwort records from Omsk Province. - Arctoa 18: 267.

KONSTANTINOVA, N.A. \& A.A. VILNET. 2009. New taxa and combinations in Jungermanniales. - Arctoa 18: 65-67.

VILNET, A.A., N.A. KONSTANTINOVA \& A.V. TROITSKY. 2009. Genosystematics and new insight into the phylogeny and taxonomy of liverworts. Molecular biology 43(5): 783-793.

[VILNET, A.A., N.A. KONSTANTINOVA \& A.V. TROITSKY] ВИЛЬНЕТ А.А., Н.А. КОНСТАНТИНОВА, А.В. ТРОИЦКИЙ. 2009. Геносистематика и новый взгляд на филогению и систему печеночников. - [Genosystematics and new insight on phylogeny and taxonomy of liverworts] Молекулярная биология [Molecular biology] 43 (5): 1-12.

[VILNET, A.A., N.A. KONSTANTINOVA \& A.V. TROITSKY] ВИЛЬНЕТ А.А., КОНСТАНТИНОВА Н.А., А.В. ТРОИЦКИЙ. 2009. Геносистематика семейства Cephaloziaceae Mig. (Marchantiophyta). - [Genosystematics of family Cephaloziaceae Mig. (Marchantiophyta)] В кн.: Кариология, кариосистематика и молекулярная систематика растений: Матер. 6-го совещзания (конференции). [In: Karyologiya, karyosystematica i molecularnaya systematica rasteniy: Materialy 6-go soveshaniya (konferentsii)] СанкmПетербург [St.-Petersburg]: 78-81.

[AKATOVA, T.V., M.S. IGNATOV, E.A. IGNATOVA \& N.A. KONSTANTINOVA] AKATOBA T.B., М.С. ИГНАТОВ, Е.А. ИГНАТОВА, Н.А. КОНСТАНТИНОВА. 2010. Видовое разнообразие мохообразных и проблемы его сохранения на Западном Кавказе. - [Bryophyte Diversity and problems of its conservation in the Western Caucasus] $B$ кн.: Бриология: традиции и современность. Сборник статей по материалам международной бриологической конферениии, посвященной 110-летию со дня рождения Зои Николаевны Смирновой и Клавдии Ивановны Ладыженской, Санкт-Петербург, 11-15 октября 2010 2. [In: Bryology: traditions and state-of-the-art. Proceedings of the international bryological conference devoted to the 110-th birthdays of Zoya Nikolaevna Smirnova and Claudia Ivanovna Ladyzhenskaja. Saint Petersburg, October 1115, 2010] Санкт-Петербург. [St.-Petersburg]: 21-25.

[AKATOVA, T.V., M.S IGNATOV \& N.A. KONSTANTINOVA] АКАТОВА Т.В., М.С. ИГНАТОВ, Н.А. КОНСТАНТИНОВА. 2010. К бриофлоре низкогорий республики Адыгея (бассейн р. Белая). - [On the bryophyte flora of a low mountain landscape of Adygeya Republic (Belaya River Basin)] В кн.: Матер. ХХI Недели науки МГТУ. ХVI Междунар. науч.-практ. конф. «Экологические проблемы современности. Рациональное природопользование и сохранение биоразнобразия». T. III [In: Materialy XXI
Nedeli nauki MGTU. XVI Mezhdunarodnaya nauchno-prakticheskaya konferentsiya "Ekologicheskie problemy sovremennosti. Ratsional'noe prirodopol'zovanie i sokhranenie bioraznoobraziya". Vol. III] Maйкоn [Maikop]: 120-128.

[KONSTANTINOVA, N.A.] КОНСТАНТИНОВА Н.А. 2010. К фитогеографии печеночников Южной Сибири. - [On the phytogeography of liverworts (Marchantiophyta) of South Siberia] В кн.: Проблемы изучения и сохранения растительного мира Евразии: Материалы Всероссийской конференции с международным участием, посвященной памяти Л.В. Бардунова [In: Problemy izucheniya i sokhraneniya rastitelnogo mira Evrasii: Materialy Vserossiyskoy konferentsii s mezhdunarodnym uchastiem, posvyachennoi pamyati L.V. Bardunova] Иркутск [Irkutsk]: 111-113.

[KONSTANTINOVA, N.A., A.G. BEZGODOV \& A.N. SAVCHENKO] КОНСТАНТИНОВА Н.А., А.Г. БЕЗГОДОВ, А.Н. САВЧЕНКО. 2010. Печеночники заповедника Басеги (Пермская область). - [Hepatics of Basegi State Nature Reserve (Perm Province)] Новости систематики низиих растений [Novosti sistematiki nizshikh rastenij] 44: 322-336.

KONSTANTINOVA, N.A. \& Yu.S. MAMONTOV. 2010. A revision of the genus Calycularia Mitt. (Calyculiariaceae, Marchantiophyta). - Arctoa 19: 117-130.

KONSTANTINOVA, N.A. \& Yu.S. MAMONTOV. 2010. Notes on Calycularia Mitt. (Marchantiophyta) in Russia. - In: International conference "Bryoflora of the Russian Far East: taxonomy, genesis, phytogeographic relations", Vladivostok, 3-12 September 2010. Vladivostok: 40-42.

KONSTANTINOVA, N.A. \& A.N. SAVCHENKO. 2010. New liverwort records from Karachaevo-Cherkessian Republic. I. - Arctoa 19: 272.

KONSTANTINOVA, N.A. \& A.N. SAVCHENKO. 2010. New liverwort records from Republic of Adygeya I. - Arctoa 19: 270.

[KONSTANTINOVA, N.A. \& A.N. SAVCHENKO] KOHСТАНТИНОВА Н.А., А.Н. САВЧЕНКО. 2010. К фитогеографии печеночников Кавказа. - [On the phytogeography of Caucasian hepatics] В кн.: Изучение флоры Кавказа. Тезисы докл. междунар. науч. конф. (Пятигорск, 27 сентября - 1 октября 2010 г.) [In : Izuchenie flory Kavkaza. Tezisy dokladov mezhdunarodnoj nauchnoj konferentsii (Pyatigorsk, September, 27 - October 1, 2010)]: 53-54.

MAMONTOV, Yu.S., N.A. KONSTANTINOVA \& O.M. AFONINA. 2010. New liverwort records from Zabaikal'sky Territory. 4. - Arctoa 19: 275-277.

[VILNET, A.A., N.A. KONSTANTINOVA \& A.V. TROITSKY] ВИЛЬНЕТ А.А., Н.А. КОНСТАНТИНОВА, А.В. ТРОИЦКИЙ. 2010. Молекулярно-филогенетический подход к ревизии рода Barbilophozia Loeske (Jungermanniales, Marchantiophyta). - [Molecular phylogenetic approach to revision of the genus Barbilophozia Loeske (Jungermanniales, Marchantiophyta)] В кн.: Проблемы изучения и сохранения растительного мира Евразии: Материаль Всероссийской конференции с международным участием, посвященной памяти Л.В. Бардунова [In: Problemy izucheniya i sokhraneniya rastitelnogo mira Evrasii: Materialy Vserossiyskoy konferentsii s mezhdunarodnym uchastiem, posvyachennoi pamyati L.V. Bardunova] Иркутск [Irkutsk]: 230-233. 
VILNET, A.A., N.A. KONSTANTINOVA \& A.V. TROITSKY. 2010. Molecular phylogenetic studies of liverworts: progress and prospects. - In: Proceedings of International conference "Bryoflora of the Russian Far East: taxonomy, genesis, phytogeographic relations", Vladivostok: 51-52.

VILNET, A.A., N.A. KONSTANTINOVA \& A.V. TROITSKY. 2010. On molecular phylogeny and systematics of suborder Cephaloziineae (Jungermanniales, Marchantiophyta). - In: Molecular phylogenetics: Contributions to the $2^{\text {nd }}$ Moscow International Conference. Moscow: 180-181.

VILNET, A.A., N.A. KONSTANTINOVA \& A.V. TROITSKY. 2010. Molecular insight on phylogeny and systematics of the Lophoziaceae, Scapaniaceae, Gymnomitriaceae and Jungermanniaceae. - Arctoa 19: 31-50.

[IGNATOVA, E.A., M.S. IGNATOV, V.E. FEDOSOV \& N.A. KONSTANTINOVA] ИГНАTOBA Е.A., М.С. ИГНАТОВ, В.Э. ФЕДОСОВ, Н.А. КОНСТАНТИНОВА. 2011. Краткий определитель моховидных Подмосковья. - [Bryophytes of Moscow Province: a guide $]$ Москва, КMК [Moscow, KMK], $320 \mathrm{pp}$.

KONSTANTINOVA, N.A. 2011. Contribution to the hepatic flora of the Republic of Dagestan (Eastern Caucasus, Russia). - Arctoa 20: 175-182.

[KONSTANTINOVA, N.A., O.A. BELKINA, E.A. BOROVICHEV, D.A. DAVYDOV, T.P. DRUGOVA, V.A. KOSTINA, L.A. KONOREVA, N.E. KOROLEVA, A.V. MELEKHIN \& A.N. SAVCHENKO] КОНСТАНТИНОВА Н.A., О.А. БЕЛКИНА, Е.А. БОРОВИЧЕВ, Д.А. ДАВЫДОВ, Т.П. ДРУГОВА, В.А. КОСТИНА, Л.А. КОНОРЕВА, Н.Е. КОРОЛЕВА, А.В. МЕЛЕХИН, А.Н. САВЧЕНКО. 2011. Итоги научно-исследовательских работ лаборатории флоры и растительных ресурсов (ПАБСИ) за первое десятилетие XXI века. - [Investigations of the laboratory of flora and vegetation during the first decade of TwentyFirst Century] Вестник Кольского Научного иентра РАН. Серия естественные и технические науки [Vestnik Kol'skogo Nauchnogo Tsentra Ros. Akad. Nauk. Seriya estestvennye i tekhnicheskie nauki] 2(5): 21-33.

[KONSTANTINOVA, N.A., O.A. BELKINA, E.A. BOROVICHEV, D.A. DAVYDOV, V.A. KOSTINA, A.Yu. LIKHACHEV, A.V. MELEKHIN \& S.S. SHALYGIN] КОНСТАНТИНОВA Н.A., О.А. БЕЛКИНА, Е.А. БОРОВИЧЕВ, Д.А. ДАВЫДОВ, В.А. КОСТИНА, А.Ю. ЛИХАЧЕВ, А.В. МЕЛЕХИН, С.С. ШАЛЫГИН. 2011. Обзор разнообразия растений, лишайников и цианопрокариот на особо охраняемых природных территориях Мурманской области. - [Diversity of plants, lichens and cyanoprocaryota in Specially Protected Areas of Murmansk Province] Вестник Кольского Научного иентра PAH. Серия естественные и технические науки [Vestnik Kol'skogo Nauchnogo Tsentra Rossijskoj Akademii Nauk. Seriya estestvennye i tekhnicheskie nauki] 2(5): 63-73.

KONSTANTINOVA, N.A. \& G.Ya. DOROSHINA. 2011. New liverwort records from Republic of Kalmykiya I. - Arctoa 20: 256 .

[KONSTANTINOVA, N.A. \& A.N. SAVCHENKO] KOHСТАНТИНОВА Н.А., А.Н. САВЧЕНКО. 2011. К флоре печеночников Сочинского национального парка (Западный Кавказ). - [On the liverwort flora of Sochi National Park (Western Caucasus)] Новости систематики низших pacmений [Novosti sistematiki nizshikh rastenij] 45: 301-317.
[KONSTANTINOVA, N.A. \& A.N. SAVCHENKO] KOHСТАНТИНОВА Н.А., А.Н. САВЧЕНКО. 2011. О распространении Scapania ligulifolia R.M. Schust. (Hepaticae) на Шпицбергене. - [About distribution of Scapania ligulifolia R.M. Schust. (Hepaticae) in Svalbard] В кн.: Глобальные климатические процессы и их влияние на экосистемы арктических и субарктических регионов [In: Global'nye klimaticheskie processy $i$ ikh vliyanie na ecosistemy arcticheskikh i subarcticheskikh regionov] Мурманск [Murmansk] 11: 96-97.

KONSTANTINOVA, N.A. \& A.A. VILNET. 2011. Jubula hutchinsiae ssp. caucasica subsp. nov. (Jubulaceae, Marchantiophyta) - new taxon from western Caucasus. - Arctoa 20: $227-238$.

MAMONTOV, Yu.S., N.A. KONSTANTINOVA \& O.M. AFONINA. 2011. New liverwort records from Zabaikal'sky Territory. 5. - Arctoa 20: 259-261.

TROITSKY, A.V., A.A. VILNET, N.A. KONSTANTINOVA \& V.K. BOBROVA. 2011. Family Cephaloziaceae s.l. (Jungermanniales, Marchantiophyta): unraveling phylogeny from molecular approach. - In: Botaniker tagung 2011. Conference Book. Berlin: 193.

[VILNET, A.A. \& N.A. KONSTANTINOVA] ВИЛЬНЕT A.A., Н.А. КОНСТАНТИНОВА. 2011. Молекулярно-филогенетические исследования - новый подход к систематике печеночников. - [Molecular phylogenetic studies - a new approach to systematics of liverworts] Вестник Кольского научного иентра PAH [Vestnik Kol'skogo nauchnogo centra RAN] 2: 40-45.

[VILNET, A.A., N.A. KONSTANTINOVA \& V.A. BAKALIN] ВИЛЬНЕТ А.А., Н.А. КОНСТАНТИНОВА, В.А. БАКАЛИН. 2011. Молекулярно-генетический полиморфизм видов Jungermannia L. s.l. (Hepaticae): современный подход к ревизии рода. - [Molecular-genetic polymorphism of Jungermannia L. s.l. (Hepaticae) species: modern approach to the revision of the genus] В кн.: Биологическое разнообразие: Генофонды и генетическое разнообразие: сборник материалов [In: Biologicheskoe raznoobrazie: genofondy i geneticheskoe raznoobrazie: sbornik materialov] Москва [Moscow]: 15-17.

VILNET, A.A., N.A. KONSTANTINOVA \& A.V. TROITSKY. 2011. Molecular phylogenetic approach to study of the earliest land plants: the family Cephaloziaceae Mig. s.l. (Marchantiophyta). - In: Proceedings of the international Moscow conference on computational molecular biology. Moscow: 386-387.

VILNET, A.A., N.A. KONSTANTINOVA \& A.V. TROITSKY. 2011. Taxonomical rearrangements of Solenostomataceae (Marchantiophyta) with description of a new family Endogemmataceae based on trnL-F cpDNA analysis. - Folia Cryptogamica Estonica. 48: 125-133.

[BELKINA, O.A., I.V. BLINOVA, E.A. BOROVICHEV, T.V. DEMAKHINA, K.N. KOBYAKOV, D.B. KOLTSOV, L.A. KONOREVA, N.A.KONSTANTINOVA, N.E. KOROLEVA, V.A. KOSTINA, A.Yu. LIKHACHEV, A.V. MELEKHIN, V.N. PETROV, M.Yu. PLETS, I.N. URBANAVICHENE \& G.P. URBANAVICHUS] БЕЛКИНА О.А., И.В. БЛИНОВА, Е.А. БОРОВИЧЕВ, Т.В. ДЕМАХИНА, К.Н. КОБЯКОВ, Д.Б. КОЛЬЦОВ, Л.А. КОНОРЕВА, Н.А. КОНСТАНТИНОВА, Н.Е. КОРОЛЕВА, В.А. КОСТИНА, А.Ю. 
ЛИХАЧЕВ, А.В. МЕЛЕХИН, В.Н. ПЕТРОВ, М.Ю. ПЛЕЦ, И.Н. УРБАНАВИЧЕНЕ, Г.П. УРБАНАВИЧЮС. 2011-2013. Территории особого природоохранного значения Мурманской области. - [Special Areas of Conservation of the Murmansk Region] В кн.: Изумрудная книга Российской Федерачии. Территории особого природоохранного значения Европейской России. Предложения по выявлению. Ч. 1 (ред. Соболев Н.А., Е.А. Белановская) [In: Sobolev, N.A. \& E.A. Belanovskaya (eds.) Izumrudnaya kniga Rossijskoj Federatsii. Territorii osobogo prirodookhrannogo znachenia Evropejskoj Rossii. Predlozheniya po vyyavleniyu, Chast' 1] Москва [Moscow]: 41-51.

BOROVICHEV, E.A. \& N.A. KONSTANTINOVA. 2012. Sauteria Nees and Peltolepis Lindb. (Cleveaceae, Marchantiophyta) in the Russian Far East. - In: Abstracts of International conference the East Asian Flora and its rolle in the formation of the worlds vegetation. Vladivostok, Russia, September, 23-27, 2012. Vladivostok: 11.

BOROVICHEV, E.A., N.A. KONSTANTINOVA \& E.N. ANDREJEVA. 2012. The genus Sauteria Nees (Cleveaceae, Marchantiophyta) in Russia. - Arctoa 21: 181-188.

KONSTANTINOVA, N.A. 2012. Contribution of R.N. Schljakov (1912-1999) to the Russian Bryology. - In: Abstracts of the International bryological conference dedicated to 100 year anniversary of R.N. Schljakov. Apatity: 5-8.

KONSTANTINOVA, N.A. 2012. Hepatics in regional Red Data Books of European part of Russia. - In: Abstracts of 8-th Conference of European Committee for Conservation of Bryophytes. Budapest: 19-20.

[KONSTANTINOVA, N.A., O.M. AFONINA \& A.D. POTEMKIN] КОНСТАНТИНОВА Н.А., О.М. АФОНИНА, А.Д. ПОТЕМКИН. 2013. International Bryological Conference devoted to 100 Anniversary of R.N. Schljakov (Apatity, Murmansk Region, 24-26 June 2012, Apatity) and field school "Bryophytes of Subarctic" for beginners in bryology (Apatity, Murmansk Region, 27-30 June 2012, Apatity). Ботанический журнал [Botanicheskij Zhurnal] 98(3): 398404.

KONSTANTINOVA, N.A., M.S. IGNATOV \& E.E. PERKOVSKY. 2012. Hepatics from Rovno umber (Ukraine). - Arctoa 21: 265-271.

KONSTANTINOVA, N.A. \& A.N. SAVCHENKO. 2012. Contribution to the Hepatic flora of the Nordaustlandet (Svalbard). I. Hepatics of the north coast of Murchison Fjorden. Polish Botanical Journal 57(1): 181-195.

[KONSTANTINOVA, N.A. \& A.N. SAVCHENKO] KOHСТАНТИНОВА Н.А., А.Н. САВЧЕНКО. 2012. К флоре печеночников Кавказского заповедника. - [On the liverworts flora of the Caucasian Reserve] В кн.: Труды Кавказского государственного природного биосферного заповедника, Bып. 20 (ред. Акатов В.В., Т.В. Акатова, С.А. Tpenem) [In: Akatov, V.V., T.V. Akatova \& S.A. Trepet (eds.) Trudy Kavkazskogo Gosudarstvennogo Prirodnogo Biosfernogo Zapovednika. Vyp. 20] Maйкоn [Maikop]: 61-83.

[KONSTANTINOVA, N.A. \& A.N. SAVCHENKO] KOHСТАНТИНОВА Н.А., А.Н. САВЧЕНКО. 2012. Печеночники окрестностей поселка Лазаревское (Западный Кавказ, Россия). - [Liverworts of Lazarevskoe Settlement vicinity (Western Causasus, Russia)] Чорноморський ботанічний журнал [Chornomorskij botanichnij zhurnal] 8(1): 56-66.
KONSTANTINOVA, N.A., A.N. SAVCHENKO \& A.A. VILNET. 2012. Should endemic hepatics of Caucasus be included in the new Red Data Book of Europe? - In: Abstracts of 8-th Conference of European Committee for Conservation of Bryophytes. Budapest: 20.

KONSTANTINOVA, N.A., L. SÖDERSTRÖM, A. HAGBORG, M. VON KONRAT. 2013. Notes on early land plants today. 15. Apotreubia hortoniae validated (Treubiaceae, Marchantiophyta). - Phytotaxa 76(3): 33.

[LAPSHINA, E.D. \& N.A. KONSTANTINOVA] ЛАПШИНА Е.Д., Н.А. КОНСТАНТИНОВА. 2012. Печеночники (Marchantiophyta) равнинной части Ханты-Мансийского автономного округа (Западная Сибирь). - [Hepatics (Marchantiophyta) of the plain of the Khanty-Mansijsk Autonomous District (West Siberia)] Arctoa 21: 85-92.

MAMONTOV, Yu.S. \& N.A. KONSTANTINOVA. 2012. On distribution of Moerckia flotoviana (Nees) Schiffn. (Moerckiaceae, Marchantiophyta). - In: Abstracts of the International bryological conference dedicated to 100 year anniversary of R.N. Schljakov. Apatity: 56-57.

[MAMONTOV, Yu.S. \& N.A. KONSTANTINOVA] MAMOHТОВ Ю.С., Н.А. КОНСТАНТИНОВА. 2012. К распространению Moerckia flotoviana (Nees) Schiffn. (Moerckiaceae, Marchantiophyta). - [On distribution of Moerckia flotoviana (Nees) Schiffn. (Moerckiaceae, Marchantiophyta)] Чорноморський ботанічний журнал [Chornomorskij botanichnij zhurnal] 8(1): 38-48.

VILNET, A.A., V.A. BAKALIN, N.A. KONSTANTINOVA \& A.V. TROITSKY. 2012. The infraspecific molecular variation in Hygrobiella laxifolia (Hook.) Spruce (Marchantiophyta, Hygrobiellaceae). - In: Contributions to the $3^{\text {rd }}$ Moscow International Conference "Molecular Phylogenetics" (MolPhy). Moscow: 37.

VILNET, A.A., N.A. KONSTANTINOVA \& A.V. TROITSKY. 2012. Molecular phylogenetic data on reticulate evolution in the genus Barbilophozia Loeske (Anastrophyllaceae, Marchantiophyta) and evidence of non-concerted evolution of rDNA in Barbilophozia rubescens allopolyploid. - Phytotaxa 49: 6-22.

VILNET, A.A., N.A. KONSTANTINOVA \& A.V. TROITSKY. 2012. Molecular phylogeny and systematics of the suborder Cephaloziineae with special attention to the family Cephaloziaceae s.1. (Jungermanniales, Marchantiophyta). - Arctoa 21: 113-132.

VILNET, A.A., N.A. KONSTANTINOVA \& A.V. TROITSKY. 2012. The requirement of taxonomical rearrangements in Cephaloziaceae s.1. from molecular data. - In: Abstarcts and Program of the $3^{\text {rd }}$ International Symposium on Molecular systematics of Bryophytes. NY: 82.

KOBYAKOV, K.N., L.G. ISAEVA, S.V. KOBYAKOVA, N.A. KONSTANTINOVA, N.E. KOROLEVA, V.A. KOSTINA, V.N. PETROV, O.V. PETROVA \& N.A. SOBOLEV] КОБЯКОВ К.Н., Л.Г. ИСАЕВА, С.В. КОБЯКОВА, Н.А. КОНСТАНТИНОВА, Н.Е. КОРОЛЁВА, В.А. КОСТИНА, В.Н. ПЕТРОВ, О.В. ПЕТРОВА, Н.А. СОБОЛЕВ. 2013. ВЫбор экологически приемлемых вариантов размещения промышленной транспортной инфраструктуры в Хибинском горном массиве. - [The environmentally friendly accommodation options for industrial transport infrastructure in the Khibiny Mts.] В кн.: Рациональное природопользование: 
традиции и инновачии (ред. Слипенчук M.B.) [In: Slipenchuk, M.V. (ed.) Racional'noe prirodopol zovanie: traditsii i innovatsii] Москва [Moscow]: 163-167.

[KONSTANTINOVA, N.A.] КОНСТАНТИНОВА Н.А. 2013. Печеночники. - [Liverworts] В кн.: Красная книга Республики Адыгея. Редкие и находящиеся под угрозой исчезновения объекты животного и растительного мира. Ч. 1 . Растения и грибы [In: Red Data Book of Republic of Adygeya. Rare and threatened representatives of the regional fauna and flora. Part 1. Introduction, Vegetabilia and Mycota] Maŭkon [Majkop]: 212-218.

KONSTANTINOVA, N.A. \& A.N. SAVCHENKO. 2013. Russian Caucasus distribution of fourteen hepatics rare and threatened in Europe. - Polish Botanical Journal 58(2): 573-584.

KONSTANTINOVA, N.A., A.A. VILNET, L. SÖDERSTRÖM, A. HAGBORG \& M. VON KONRAT. 2013. Notes on early land plants today. 14. Transfer of two Macrodiplophyllum species to Douinia (Scapaniaceae, Marchantiophyta). - Phytotaxa 76(3): 31-32.

[TISHKOV, A.A., N.A. KONSTANTINOVA, E.A. SHVARTS, K.N. KOBYAKOV, N.E. KOROLEVA, V.N. PETROV, N.A. SOBOLEB, M.A. VIKULINA, L.G. ISAEVA, S.V. TITOVA, V.A. KOSTINA, O.V. PETROVA, S.K. KONYAEV \& E.P. GURINA] ТИШКОВ А.А., Н.А. КОНСТАНТИНОВА, Е.А. ШВАРЦ, К.Н. КОБЯКОВ, Н.Е. КОРОЛЕВА, В.Н. ПЕТРОВ, Н.А. СОБОЛЕВ, М.А. ВИКУЛИНА, Л.Г. ИСАЕВА, С.В. ТИТОВА, В.А. КОСТИНА, О.В. ПЕТРОВА, С.К. КОНЯЕВ, Е.П. ГУРИНА. 2013. Анализ возможностей экологически приемлемого размещения промышленной транспортной инфраструктуры в Хибинском горном массиве (Мурманская область). - [Analysis of possibilities of accommodation of industrial transport infrastructure in Khibiny Mts. (Murmansk region)] В кн.: Использование и охрана природных ресурсов в России. Научно-техн. бюллетень [In: The use and conservation of natural resources in Russia. Scientific and Technical newsletter] 1: 51-56.

RAYNOLDS, M., A.L. BREEN, D.A. WALKER, R. ELVEN, R. BELLAND, N. KONSTANTINOVA, H. KRISTINSSON \& S. HENNEKENS. 2013. The Pan-Arctic Species List (PASL). - In: Walker, D.A., A.L. Breen, M.K. Raynolds \& M.D. Walker (eds). Arctic Vegetation Archive (AVA) Workshop, Krakow, Poland, April 14-16, 2013. CAFF Proceedings Report №10. Akureyri, Iceland: 92-95.

[VILNET, A.A. \& N.A. KONSTANTINOVA] ВИЛЬНЕT А.А., Н.А. КОНСТАНТИНОВА. 2013. Молекулярно-генетический полиморфизм листостебельных печеночников рода Liochlaena Nees. - [Molecular genetic polymorphism of the leafy liverworts genus Liochlaena Nees] В кн.: Молекулярно-генетические подходы в таксономии и экологии: тезисы докладов научной конференции (2. Ростов-наДону) [In: Molecular Genetic Approaches in Taxonomy and Ecology. Abstracts of the Scientific Conference. Ростов-наДону [Rostov-on-Don]: 27.

[VILNET, A.A., N.A. KONSTANTINOVA \& V.A. BAKALIN] ВИЛЬНЕТ А.А., Н.А. КОНСТАНТИНОВА, В.А. БАКАЛИН. 2013. Молекулярно-генетический подход в исследовании разнообразия печеночников (Marchantiophyta). [Molecular phylogenetic approach to study of liverworts diversity (Marchantiophyta)] В кн.: Современная ботаника в России. Труды ХІІІ Съезда Русского ботанического обществва и конференции «Научные основы охраны и рацио- нального использования растительного покрова Волжского бассейна» T. 1: Эмбриология. Структурная ботаника. Альгология. Микология. Лихенология. Бриология. Палеоботаника. Биосистематика. Тольятти, 16-22 сентября 2013 2. [In: Sovremennaya botanica v Rossii. Trudy XIII S'ezda Russkogo Botanicheskogo obshhestva i konferentsii "Nauchnye osnovy okhrany i racional 'nogo ispol 'zovaniya rastitel 'nogo pokrova Volzhskogo bassejna". T. 1: Embriologiya. Strukturnaya botanika. Algologia. Mikologia. Likhenologiya. Bryologiya. Paleobotanika. Biosistematika. Tolyatti, 16-22 September 2013] Тольятти [Tol'yatti]: 236-237.

[BELKINA, O.A., E.A. BOROVICHEV, T.P. DRUGOVA, N.A. KONSTANTINOVA, A. YU. LIKHACHEV, YU.S. MAMONTOV \& A.I. MAKSIMOV] БЕЛКИНА O.A., Е.А. БОРОВИЧЕВ, Т.П. ДРУГОВА, Н.А. КОНСТАНТИНОВА, А.Ю. ЛИХАЧЕВ, Ю.С. МАМОНТОВ, А.И. МАКСИМOB. 2014. Мохообразные. - [Bryophytes] В кн.: Красная Книга Мурманской области (ред. Константинова Н.А. u др.) [In: Konstantinova, N.A. et al. (eds.) Red Data Book of the Murmansk Province] Кемерово, Азия-Принт [Kemerovo, Asia-Print Publishing]: 190-308.

[BOROVICHEV, E.A., O.A. BELKINA, D.A. DAVYDOV, L.G. ISAEVA, M.N. KOZHIN, N.A. KONSTANTINOVA, V.A. KOSTINA \& G.P. URBANAVICHUS] БОРОВИЧЕВ E.A., О.А. БЕЛКИНА, Д.А. ДАВЫДОВ, Л.Г. ИСАЕВА, М.Н. КОЖИН, Н.А. КОНСТАНТИНОВА, В.А.КОСТИНА, Г.П. УРБАНАВИЧЮС. 2014. Растения, грибы и лишайники во втором издании Красной книги Мурманской области. - [Plants, fungi and lichens in the second edition of the Red Data Book of Murmansk Region] В кн.: Экологические проблемы северных регионов и пути их решения. Материаль $V$-ой Всероссийской научной конференции с международным участием (Anатиты, 2014) [In: Ecologicheskie problemy severnykh regionov i puti ikh resheniya. Materialy V Vserossiyskoj nauchnoj conferentsii s mezhdunarodnym uchastiem (Apatity, 2014)] 1: 86-91.

KONSTANTINOVA, N.A. \& V.A. BAKALIN. 2014. New liverwort records from Magadan Province 1. - In: Sofronova, E.V. (ed.) New bryophyte records. 3. Arctoa 23: 235.

[KONSTANTINOVA, N.A., O.A. BELKINA, D.A. DAVYDOV, L.A. KONOREVA \& A.A. VILNET] КОНСТАНТИНОВА Н.А., О.А. БЕЛКИНА, Д.А. ДАВЫДОВ, Л.А. КОНОРЕВА, А.А. ВИЛЬНЕТ. 2014. Современный этап и задачи изучения разнообразия печеночников, мхов, лишайников и цианопрокариот Архипелага Шпицберген. - [Modern stage and main aims in investigations of liverworts, mosses, lichens and cyanoprocaryotes diversity of Spitsbergen archipelago] Теоретическая и прикладная экология [Teoretical and applied ecology] 1: 26-31.

KONSTANTINOVA, N.A. \& E.D. LAPSHINA. 2014. On the hepatic flora of the eastern Subpolar Ural (Khanty-Mansi Autonomous District). - Arctoa 23: 80-90.

KONSTANTINOVA, N.A., L. SÖDERSTRÖM, A. HAGBORG $\&$ M. VON KONRAT. 2014. Notes on early land plants today. 51. Validation of Schistochilopsis hyperarctica (Scapaniaceae, Marchantiophyta). - Phytotaxa 162 (4): 240.

KONSTANTINOVA, N.A. \& A.A. VILNET. 2014. New liverwort records from Chukotka Autonomous District. 1. - In: Sofronova E.V. (ed.) New bryophyte records. 3. Arctoa 23: 234-235. 
KONSTANTINOVA, N.A., A.A. VILNET, L. SÖDERSTRÖM, A. HAGBORG. \& M. VON KONRAT. 2014. Notes on early land plants today. 53. Hygrobiellaceae (Marchantiophyta) validated. - Phytotaxa 167 (2): 217.

KONSTANTINOVA, N.A., A.A. VILNET \& S. ŞTEFĂNUȚ.
2014. On the distribution and variability of Bucegia romanica Radian. - Arctoa 23: 137-144.

MAMONTOV, Yu.S., N.A. KONSTANTINOVA, A.A. VILNET \& V.A. BAKALIN. 2015. On the phylogeny and taxonomy of Pallaviciniales (Marchantiophyta), with overwiew of Russian species. - Arctoa 24: 98-123. 